\title{
Daily exercise training protects against albuminuria and angiotensin converting enzyme 2 shedding in $d b / d b$ diabetic mice
}

\author{
Hari K Somineni', Gregory P Boivin ${ }^{2,3}$ and Khalid M Elased ${ }^{1}$ \\ Departments of ${ }^{1}$ Pharmacology and Toxicology and ${ }^{2}$ Pathology, Boonshoft School of Medicine, \\ Wright State University, Dayton, Ohio 45435, USA \\ ${ }^{3}$ Veterans Affairs Medical Center, Cincinnati, Ohio 45220, USA
}

Correspondence should be addressed to $\mathrm{K} M$ Elased

Email

khalid.elased@wright.edu

\begin{abstract}
Angiotensin II (Ang II) is involved in induction and progression of renal damage in diabetes. Angiotensin converting enzyme 2 (ACE2) is highly expressed in the kidney and has been shown to be renoprotective by degrading Ang II to Ang-(1-7). A disintegrin and metalloproteinase 17 (ADAM17)-mediated shedding of renal ACE2 contribute to diabetic nephropathy pathogenesis. Lifestyle modification and metformin are recommended as initial therapies for most patients with type 2 diabetes. The aim of this study was to investigate whether exercise training and/or metformin improve glucose homeostasis and albuminuria and downregulate renal ADAM17 and ACE2 shedding in $d b / d b$ mice. Seven-week-old normal and $d b / d b$ mice were subjected either to a sedentary existence or exercise training with and without metformin (150 mg/kg per day) for 10 weeks. Exercise training significantly lowered blood glucose, urinary albumin and ACE2 excretion in $d b / d b$ mice. ADAM17 and ACE2 proteins were co-localized in cortical tubules of the kidney, indicating a possible interaction. Metformin treatment was effective in lowering hyperglycemia only during the first 2 weeks of treatment. Increased renal ADAM17 in 17-week-old $d b / d b$ mice was corrected by physical exercise but not metformin. In addition, exercise training reduced plasma triglycerides and enhanced insulin levels of $d b / d b$ mice. In conclusion, exercise training alone and in combination with metformin prevented shedding of renal ACE2 by decreasing ADAM17 protein. Urinary ACE2 could serve as a prognostic tool for the progression of kidney damage and its attenuation by exercise may partially contribute to its renal protection.
\end{abstract}

\section{Key Words}

- type 2 diabetes

- urinary ACE2

- ADAM17

- diabetic nephropathy

- metformin

- exercise

\section{Introduction}

The incidence of type 2 diabetes is increasing worldwide. Lifestyle intervention programs are a cornerstone therapy for preventing (Tuomilehto et al. 2001, Knowler et al. 2002) or managing type 2 diabetes (Sigal et al. 2006). Retrospective clinical trials validated exercise training as an important non-pharmacological strategy to prevent diabetes and obesity (Pan et al. 1997). The American Diabetes Association and European Association for the Study of Diabetes recommend initiation of a pharmacological treatment concurrently with lifestyle intervention to gain tight control over diabetes and related complications (Nathan et al. 2009, Rhee et al. 2010). 
Lifestyle intervention and metformin treatment are considered to be cost-effective strategies for preventing type 2 diabetes and were associated with a reduced incidence of diabetes by 58 and 31\% respectively (Tuomilehto et al. 2001, Knowler et al. 2002, Fradkin et al. 2012). Furthermore, a randomized clinical trial conducted in individuals with impaired glucose tolerance reported that interventions with exercise, diet, and both exercise and diet were associated with 46,31 , and $42 \%$ reduction in the incidence of diabetes respectively (Pan et al. 1997), indicating the efficacy of exercise alone in preventing type 2 diabetes. However, effects of these interventions on the complications associated with diabetes are still under investigation.

Metformin is increasingly being used for the management of type 2 diabetes, especially after the adverse effects of thiazolidinediones became known. Metformin acts by stimulating 5'-AMP-activated protein kinase (AMPK), resulting in the attenuation of hepatic glucose production and enhancement of peripheral glucose uptake (Zhou et al. 2001, Scarpello \& Howlett 2008). Intensive glucose control with metformin reduced the risk of diabetes-related outcomes in overweight type 2 diabetic patients. In addition, metformin treatment has been shown to reduce plasma amylin and urinary albumin excretion in type 2 diabetic patients (Zapecka-Dubno et al. 1999, AmadorLicona et al. 2000), indicating the renoprotective efficacy. Furthermore, metformin has been reported to exert positive effects in patients with chronic kidney disease (CKD) (Pechter et al. 2003).

Moderate-intensity exercise for $150 \mathrm{~min} /$ week or vigorous-intensity exercise for $90 \mathrm{~min} /$ week is recommended to achieve therapeutic benefits for type 2 diabetes (Physical Activity Guidelines Advisory Committee 2008, American Diabetes Association 2013). Results of a Finnish diabetes prevention study demonstrated reduced incidence of type 2 diabetes even 3 years after termination of lifestyle intervention (Lindstrom et al. 2006). The mechanism for improvement may be one of several benefits of exercise. For example, exercise training is implicated in preventing diabetic complications by lowering blood sugars, ameliorating the lipid profile, and enhancing insulin sensitivity (Zinman \& Vranic 1985, Arakawa 1993). In addition, moderate-intensity exercise is associated with decreased inflammatory markers (interleukin 6, tumor necrosis factor $\alpha$, and C-reactive protein) in healthy, older subjects (Colbert et al. 2004).

Animal models of diabetes revealed similar and additional information. One study demonstrated improved glucose homeostasis following exercise training in high-fat-fed mice via upregulation of plasma irisin (Bostrom et al. 2012). Physical exercise also attenuated albuminuria, proteinuria and glomerular sclerosis and maintained podocyte number in rodent models (Kohzuki et al. 2001, Tufescu et al. 2008, Ishikawa et al. 2012). In addition, exercise training was shown to mitigate mesangial matrix expansion, tubulointerstitial fibrosis (Ghosh et al. 2009) and advanced glycation end products (Boor et al. 2009). Some studies on rodent models have validated the beneficial effect of exercise on renal and cardiac renin-angiotensin system (RAS) components (Pereira et al. 2009, Fernandes et al. 2011) by degrading angiotensin II (Ang II), and Ang II type 1 receptors (Ciampone et al. 2011) and enhancing angiotensin converting enzyme 2 (ACE2) (Cunha et al. 2010).

This study focused on the effects of exercise and metformin on the kidney. Several enzymes are known to be altered in diabetic patients. ACE2 is a membrane-bound metallopeptidase, which has been shown to have renoprotective activity through degradation of Ang II to Ang-(1-7), a biologically active peptide that contravenes the negative effects of Ang II by interacting with the G-protein-coupled receptor Mas (Tipnis et al. 2000). Recent studies demonstrated the presence of active ACE2 in the urine of human subjects and animal models (Shaltout et al. 2009, Quan et al. 2010, Chappell 2013). In patients with CKD (Mizuiri et al. 2011) as well as in renal transplant (Xiao et al. 2012), urinary ACE2 excretion is increased compared with healthy subjects. Furthermore, Wang et al. (2008) reported a strong correlation between urinary ACE2 mRNA levels and proteinuria in type 2 diabetic humans with nephropathy, indicating that urinary ACE2 could have clinical applications.

A disintegrin and metalloproteinase 17 (ADAM17) is the most active sheddase among metalloproteinase's and is involved in a broad spectrum of diseases (Kaneko et al. 2011) including diabetes (Federici et al. 2005). A recent study using type 1 diabetic mouse model demonstrated that hyperglycemia results in the activation of renal ADAM17 (Ford et al. 2013). A study conducted on Ang IIinfused mice demonstrated increased ADAM17 protein levels in the kidney, indicating a role of Ang II in activation and enhancement of ADAM17 (Lautrette et al. 2005). In vitro studies conducted separately by Lambert et al. (2005) and Salem et al. (2014) demonstrated the role of ADAM17 in ectodomain shedding of ACE2 from stably transfected HEK293 cells and endogenously expressing Huh7 cells (Lambert et al. 2005) and human renal proximal tubular HK-2 cells (Salem et al. 2014). Furthermore, in a recent study, we have demonstrated the potential role of ADAM17 in regulating ectodomain

Published by Bioscientifica Ltd. 
shedding of renal ACE2 in $d b / d b$ mice (Chodavarapu et al. 2013). Owing to its involvement in various deleterious activities, ADAM17 could be a prime target for developing therapies (Lautrette et al. 2005, Kaneko et al. 2011).

Based on the above findings, we proposed the hypothesis that intervention with physical exercise training and/or metformin would improve insulin resistance, and glucose control, decrease urinary albumin, correct renal ADAM17 protein levels, attenuate ACE2 shedding, and delay the progression of diabetic nephropathy. We herein report that exercise improved insulin resistance, and glucose control, decreased urinary albumin and ACE2 excretion and attenuated renal ADAM17, mesangial matrix expansion and collagen deposition in type 2 diabetic $d b / d b$ mice.

\section{Materials and methods}

\section{Animals}

Six-week-old male $d b / d b$ (BKS.Cgm $+/+$ Lepr $^{d b / /}$ ) mice and their age-matched non-diabetic littermates $(d b / m)$ were purchased from Jackson Laboratories (Bar Harbor, ME, USA). The genetically diabetic mouse $(d b / d b)$ has a mutation on chromosome 4 that inhibits the expression of leptin receptor (Hummel et al. 1966). The syndrome of type 2 diabetes mellitus in $d b / d b$ mice is similar to that in adult humans and is characterized by hyperinsulinemia, obesity, and progressive hyperglycemia. Animals were housed in standard cages at $22^{\circ} \mathrm{C}$ under a $12 \mathrm{~h}$ light: $12 \mathrm{~h}$ darkness cycle with ad libitum access to water and standard mouse chow. All experimental protocols were approved by Wright State University Animal Care and Use Committee (Animal use protocol number 'AUP 917').

\section{Treatment with exercise and/or metformin}

At 7 weeks of age, $d b / d b$ and $d b / m$ (non-diabetic) mice were subjected to sedentary or exercise regimens with and without metformin treatments for 10 weeks. They were randomly divided into the following groups: i) non-diabetic mice receiving regular water (control); ii) non-diabetic mice receiving metformin in drinking water; iii) non-diabetic mice receiving regular water and subjected to exercise daily $(1 \mathrm{~h} /$ day at a moderate intensity for 10 weeks); iv) nondiabetic mice receiving metformin in their drinking water and exercising daily; v) $d b / d b$ group receiving regular water; vi) $d b / d b$ group receiving metformin in drinking water; vii) $d b / d b$ group receiving regular water and exercising daily; and viii) $d b / d b$ group receiving metformin and exercising daily. Metformin (Spectrum Laboratories, New Brunswick,
NJ, USA) was added to drinking water, and the concentration was adjusted to deliver $150 \mathrm{mg} / \mathrm{kg}$ body weight per day. Exercised mice ran on a mouse forced exercise walking wheel system (Lafayette Instrument, Lafayette, IN, USA). The mice began wheel running for $1 \mathrm{~h} /$ day and 7 days/week. Initial speed was set at $4 \mathrm{~m} / \mathrm{min}$ and daily increased by $1 \mathrm{~m} / \mathrm{min}$ and reached $8 \mathrm{~m} / \mathrm{min}$ by the end of first week of training. In subsequent weeks, the mice were run for $1 \mathrm{~h} /$ day at $8 \mathrm{~m} / \mathrm{min}$. Mice were exercised during the end of the period of darkness of the light:darkness cycle. Mice were monitored weekly for blood glucose, body weight, food intake, water intake, and urine output. Following 10 weeks of treatment and $24 \mathrm{~h}$ after the last bout of exercise, mice were killed by decapitation and trunk blood was collected in ice-chilled heparinized tubes and centrifuged at $10000 \mathrm{~g}$ for $10 \mathrm{~min}$ at $4{ }^{\circ} \mathrm{C}$. Plasma was immediately separated and stored at $-80^{\circ} \mathrm{C}$. Kidneys were collected in dry ice and stored at $-80^{\circ} \mathrm{C}$.

\section{Measurement of blood glucose and glucose tolerance test}

FreeStyle Blood Glucose Test Strips \& FreeStyle Lite Blood Glucose Monitoring System 117 (Abbott Diabetes Care, Inc.) were used to measure blood glucose levels. A small cut was made on the tip of the tail vein to collect a drop of blood. Values were expressed in $\mathrm{mmol} / \mathrm{l}$. For the glucose tolerance test, mice were fasted for $16 \mathrm{~h}$ (Chodavarapu et al. 2013) and blood samples were collected at $0,30,60,90$, and $120 \mathrm{~min}$ after an i.p.-injected glucose load $(1.5 \mathrm{~g} / \mathrm{kg})$.

\section{Body composition measurement}

Body composition was measured using an ECHO MRI absolute body composition analyzer (Houston, TX, USA). The instrument was calibrated and the mouse was placed in a transparent plastic cylinder and held in position with a plastic plunger to avoid any movements. This setup was placed inside the instrument and the measurements were taken.

\section{Urine collection}

For 24-h urine collection, mice were housed individually in metabolic cages with free access to food and water. Urine samples were collected in the presence of protease inhibitor (Roche Diagnostics). The first collection was done at the end of the 12th hour and samples were stored at $4{ }^{\circ} \mathrm{C}$ until the second collection. After the second collection at the 24 th hour, samples were centrifuged at $10000 \mathrm{~g}$ for $3 \mathrm{~min}$ at $4{ }^{\circ} \mathrm{C}$. Then the supernatant was separated from the debris. Final volumes were recorded, aliquoted accordingly, and stored at $-80{ }^{\circ} \mathrm{C}$.

Published by Bioscientifica Ltd. 


\section{Urinary albumin assay}

The quantitative estimation of urinary albumin was performed using a kit purchased from Bethyl Laboratories (Montgomery, TX, USA) according to the kit instructions. A 96-well plate was coated with a goat anti-mouse albumin antibody. Samples were diluted according to the kit's protocol, added to the 96-well plate, and incubated for an hour at RT. Then, the plate was washed, diluted HRP-conjugated secondary antibody was added, and incubated for an hour at RT. TMB substrate was added and the reaction was stopped using stop solution $\left(1 \mathrm{M} \mathrm{H}_{2} \mathrm{SO}_{4}\right)$. The absorbance was measured using a Fusion Packard plate reader (Packard BioScience, Meriden, CT, USA) at $450 \mathrm{~nm}$. Unknown urinary albumin concentrations were determined from a standard curve plotted using assay standards in the range 7.8-500 ng/ml.

\section{Urinary creatinine assay}

Urinary creatinine assays were performed using a kit purchased from Quidel (San Diego, CA, USA) as described previously (Chodavarapu et al. 2013). The plate was read using a Fusion Packard plate reader at $490 \mathrm{~nm}$. Unknown urinary creatinine concentrations were determined from a standard curve plotted using assay standards.

\section{ACE2 activity}

Urinary and renal ACE2 activities were measured by fluorometric test assay. The potential of ACE2 protein to cleave the fluorogenic substrate, 7-Mca-APK-(Dnp), was used to assess the activity of ACE2. The emitted fluorescence was measured at excitation $\left(\lambda_{\mathrm{ex}}\right): 328 \mathrm{~nm}$ and emission $\left(\lambda_{\mathrm{em}}\right)$ : 393 nm using a Fusion Packard instrument (Packard BioScience). ACE2 activity was measured in the presence of $10 \mathrm{mM}$ lisinopril, an ACE inhibitor, to prevent any interference from ACE.

\section{Western blot}

Whole-kidney lysates were prepared on ice using lysis buffer containing phenylmethylsulphonyl fluoride (Complete Lysis M, Roche Diagnostics). Total protein content was determined using BSA as a standard and Bio-Rad reagent (Bio-Rad). Fifty micrograms of total protein samples were loaded and allowed to run on 10\% SDS-PAGE gel for $1 \mathrm{~h}$. After electrophoresis, proteins were electrotransferred to an activated PVDF membrane (Millipore, Billerica, MA, USA). Membranes were then blocked and probed with a polyclonal antibody directed against ACE2 (1:1000, R\&D
Systems, Minneapolis, MN, USA), ADAM17 (1:500, Enzo Life Sciences, Farmingdale, NY, USA), and Timp3 (1:200, Santa Cruz Biotechnology) respectively followed by incubation with the appropriate secondary HRP-conjugated antibody. Protein signals were detected using ECL reagent and analyzed using a ChemiDoc imaging system (Bio-Rad, Hercules, CA, USA). The relative amounts of proteins of interest in kidney and urine were determined by normalizing to $\beta$-actin and creatinine respectively.

\section{Kidney histology}

As we described in our previous study (Chodavarapu et al. 2013), kidney sections ( $4 \mu \mathrm{m}$ thick) from perfused mice were fixed in 10\% neutral buffered formalin, dehydrated through a gradient of alcohols and xylene, embedded in paraffin, and stained with periodic acid Schiff's base or picro-Sirius red using Weigert's iron hematoxylin staining kit (ENG Scientific, Inc., Clifton, NJ, USA) for histopathological observations. A total of 15-20 glomeruli from a representative mouse were analyzed for glomerular hypertrophy and mesangial matrix expansion. MetaMorph Software (Molecular Devices, Sunnyvale, CA, USA) was used for quantitation.

\section{Immunohistochemistry}

Kidney sections ( $4 \mu \mathrm{m}$ thick) were stained using standard techniques as described previously (Chodavarapu et al. 2013). Slides were incubated either with primary polyclonal goat anti-ACE2 (1:150, R\&D) or rabbit anti-ADAM17 (1:100, Enzo Life Sciences) overnight at $4{ }^{\circ} \mathrm{C}$. Washings were repeated and the sections were incubated with biotinylated donkey anti-goat or anti-rabbit IgG secondary antibody conjugated with cyanine 3 fluorescent dye. MetaMorph Software (Molecular Devices) was used for quantitation.

\section{Plasma hormone and lipids measurement}

Plasma samples collected at the end of the study were analyzed for insulin, glucose, adiponectin, leptin, glucagon, total cholesterol, and triglyceride levels at the Mouse Metabolic Phenotyping Centre (Cincinnati, OH, USA) as described previously (Chodavarapu et al. 2013).

\section{Correlations}

To identify statistically significant relationships between urinary ACE2 and albuminuria, blood glucose, and plasma risk factors, Pearson correlations were calculated between these variables for all 80 mice.

Published by Bioscientifica Ltd 


\section{Statistical analysis}

The differences among groups were compared by Student's unpaired two tailed $t$-test. For more than two groups, one-way ANOVA was used. All the values are expressed as means \pm s.E.M. For multiple comparisons between two or more groups, two-way ANOVAs were carried out followed by Bonferroni's multiple comparison tests. The level of significance was set at $P<0.05$. All the data were analyzed using GraphPad Prism 5.01 and Statistica Software (v.10) (La Jolla, CA, USA).

\section{Results}

\section{Effects of exercise and metformin on blood glucose levels and glucose tolerance}

At baseline, 7-week-old $d b / d b$ mice exhibited significantly higher blood glucose levels compared with non-diabetic mice and these were consistently higher over the study period (Fig. 1A). Moreover, $d b / d b$ mice had impaired glucose tolerance compared with non-diabetic mice, measured at the end of study (Fig. 1B and C). Physical exercise training with or without metformin lowered blood glucose levels significantly $(P<0.001$, Fig. 1A) and improved glucose tolerance in treated $d b / d b$ mice compared with untreated diabetic mice (Fig. 1B). Treatment with metformin was effective in lowering hyperglycemia during the first 2 weeks of treatment but had no effect during the later stages (Fig. 1A). No significant difference was seen between untreated, metformintreated, and exercise-trained non-diabetic mice.

\section{Effects of exercise and metformin on diet, urine output, and body composition parameters}

At baseline, $d b / d b$ mice weighed more than non-diabetic control mice. Body weights and fat mass of $d b / d b$ mice increased consistently with age compared with age-matched non-diabetic control mice (Table 1). Neither exercise training nor metformin treatment had significant effects on the body weight and fat mass of diabetic $d b / d b$ mice. In addition, $d b / d b$ mice showed significantly higher levels of food and water intake and urine output compared with control mice throughout the study period. However, exercise training alone and in combination with metformin significantly blunted food intake, water intake, and urine output of $d b / d b$ mice compared with untreated $d b / d b$ mice, whereas metformin treatment alone had no effect (Table 1). No significant differences were seen between untreated, metformin-treated, and exercise-trained non-diabetic mice.
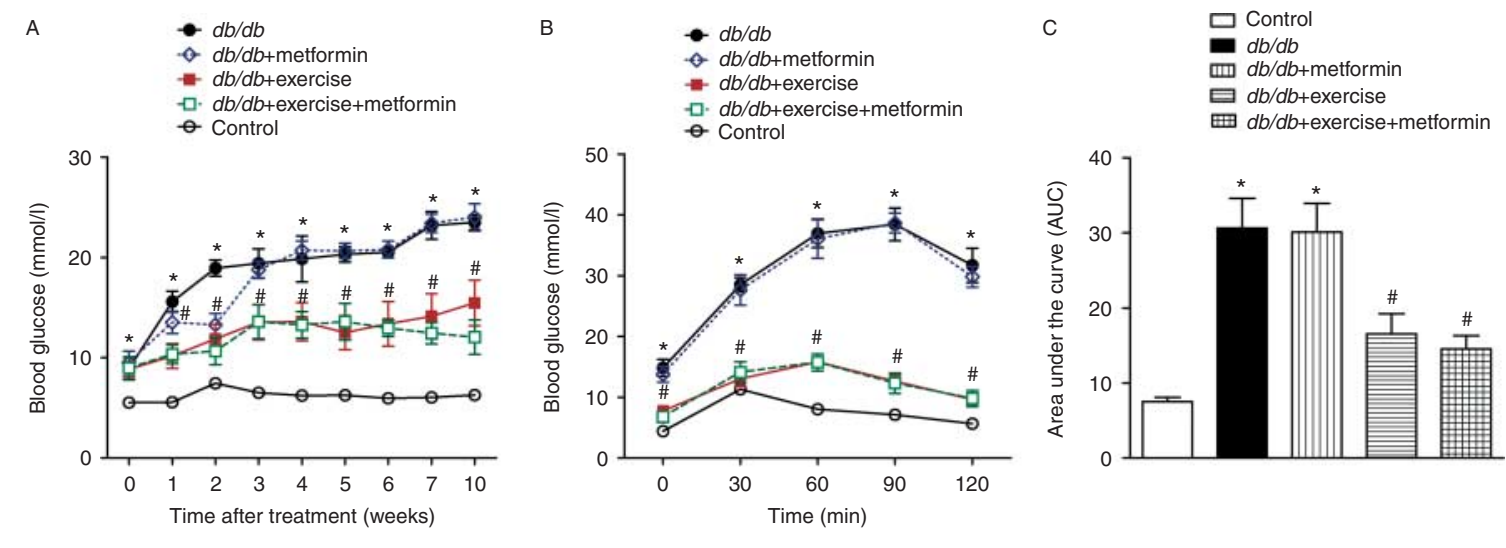

\section{Figure 1}

Exercise training and metformin improved glucose homeostasis in $\mathrm{db} / \mathrm{db}$ mice. (A) Blood glucose levels of control (untreated, non-diabetic mice), $d b / d b$ mice and $d b / d b$ mice treated with metformin, exercise, and a combination of exercise and metformin for 10 weeks. Repeated measures two-way ANOVA, followed by Bonferroni's post hoc test showed that physical exercise training alone and in combination with metformin significantly lowered hyperglycemia throughout the study period, whereas metformin was found to be effective for lowering hyperglycemia only during the first 2 weeks of treatment, $* P<0.0001$ for all $d b / d b$ groups vs age-matched control mice. ${ }^{\#} P<0.0001$ vs untreated $d b / d b$ mice. Data are represented as mean \pm s.E.M. of group size $(n=10)$. (B) Glucose tolerance test performed in control, untreated, and treated $d b / d b$ groups after the completion of 10 weeks of treatment.
Blood glucose concentrations of control, treated, and untreated $\mathrm{db} / \mathrm{db}$ mice at $0,30,60,90$, and 120 min after i.p. injection of glucose. ${ }^{\star} P<0.0001$ for untreated $d b / d b$ mice and metformin treated $d b / d b$ mice vs control (non-diabetic) mice. $\# P<0.0001$ for exercised $d b / d b$ mice vs untreated and metformin-treated $d b / d b$ mice. (C) Area under curve for the five groups. One-way ANOVA showed exercise alone and in combination with metformin improved glucose handling capacity in $d b / d b$ mice. $* P<0.0001$ for untreated $d b / d b$ mice and metformin treated $d b / d b$ mice vs control (non-diabetic) mice. $\# P<0.0001$ for exercised $d b / d b$ mice vs untreated and metformin-treated $d b / d b$ mice. Metformin treatment had no influence on glucose tolerance in diabetic mice. Data are represented as mean \pm S.E.M. of group size $(n=6)$. http://joe.endocrinology-journals.org DOI: $10.1530 / \mathrm{JOE}-13-0532$
() 2014 Society for Endocrinology Printed in Great Britain
Published by Bioscientifica Ltd. 


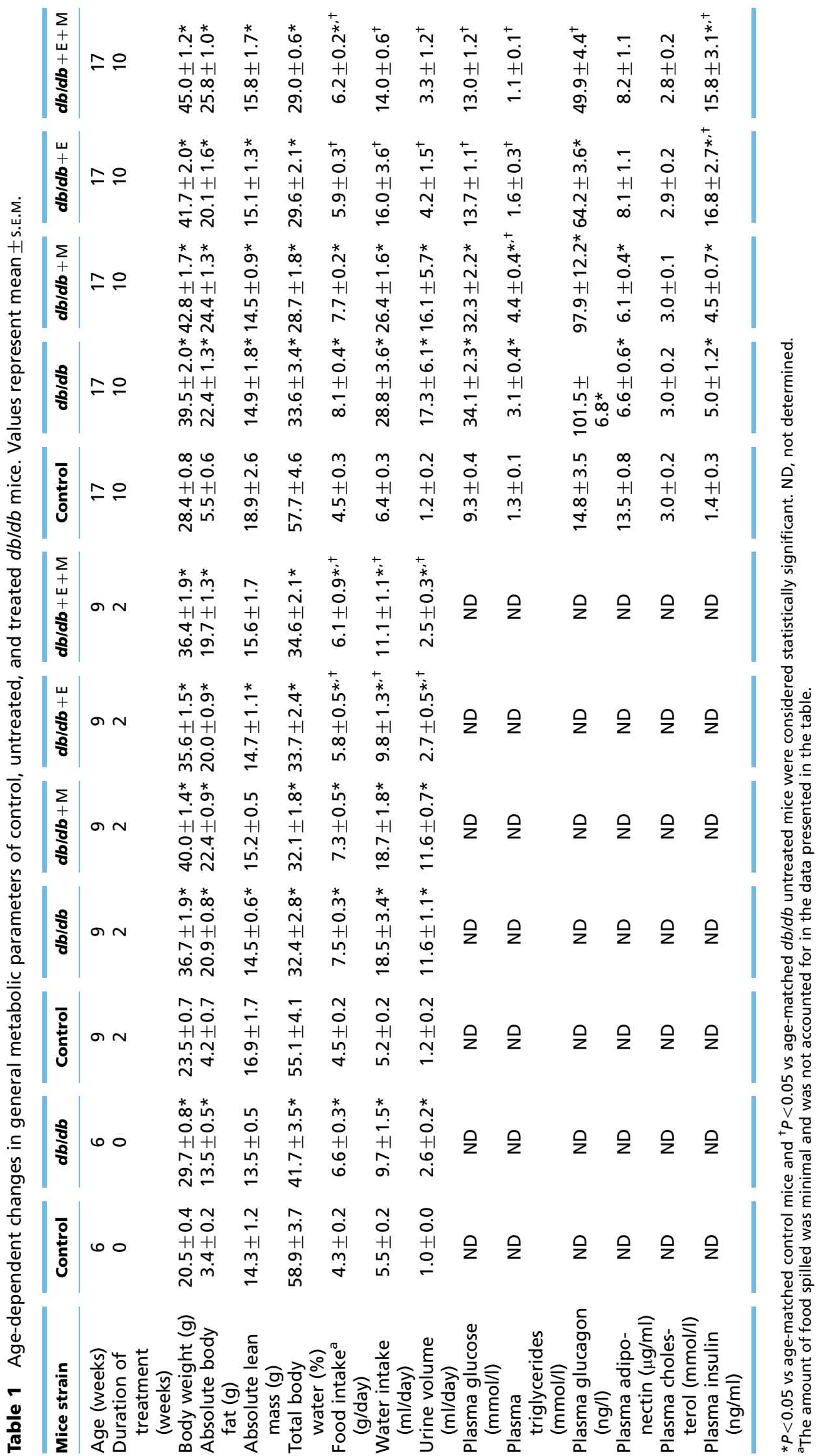




\section{Effects of exercise and metformin on indices of renal damage}

Renal damage was evaluated by measuring urinary albumin and total protein excretion. Albuminuria is one of the first clinical features of diabetic nephropathy. At 7 weeks of age (before the initiation of treatment), there was a significant increase in urinary albumin excretion levels in $d b / d b$ mice compared with non-diabetic mice. Kidney damage progressed and albumin excretion increased with age (Fig. 2A). Exercise training with or without metformin reduced albuminuria in $d b / d b$ mice. In contrast, there was a significant increase in urinary albumin levels in non-diabetic mice subjected to exercise training compared with sedentary control mice (Fig. 2C). Although metformin treatment was effective in improving albuminuria during the early stages (2 weeks after the initiation of treatment), it had no effect from 4 to 10 weeks (Fig. 2A). At 7 weeks of age (before initiation of treatment), there was no difference in urinary total protein excretion among normal and diabetic mice. With increasing age, $d b / d b$ mice excreted significantly higher levels of total protein compared with age-matched control mice. Exercise training alone and in combination with metformin reduced urinary total protein excretion to levels nearer to normal. Metformin alone had no effect on total protein excretion of $d b / d b$ mice (Fig. 2B). No significant differences were seen between untreated, metformin-treated, and exercise-trained non-diabetic mice at any time point.

\section{Effects of exercise and metformin on urinary and renal ACE2 activity}

ACE2 activity was determined using the fluorogenic substrate Mca-APK (Dnp). Urinary ACE2 activity was measured at baseline (before initiation of treatment), 2 and 10 weeks after treatment. At 7 weeks of age (before initiation of treatment), $d b / d b$ mice displayed a significant increase in urinary ACE2 activity compared with age-matched control mice (Fig. 3A, $P<0.0001$ ). Similar differences were seen over the 10-week treatment (Fig. 3A). After 2 weeks, all three treatment groups (exercised $d b / d b$, metformin-treated $d b / d b$, and exercised $d b / d b$-treated with metformin) demonstrated decreased urinary ACE2 activity compared with untreated diabetic mice. Exercise training alone and in combination with metformin continued to significantly affect urinary ACE2 activity for all 10 weeks. In contrast, metformin treatment had no effect on urinary ACE2 activity of $d b / d b$ mice after 2 weeks of treatment (Fig. 3A). There was no significant difference between untreated, metformintreated, and exercise-trained non-diabetic mice (Fig. 3C). Renal ACE2 activity from homogenized kidney lysate was significantly increased in the kidney of $d b / d b$ mice compared with age-matched non-diabetic mice (Fig. 3B). In contrast
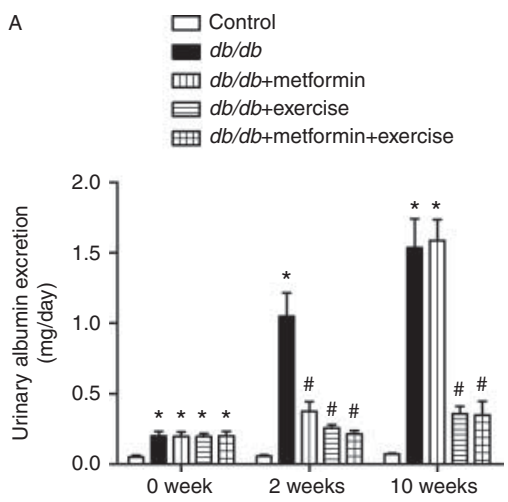

C
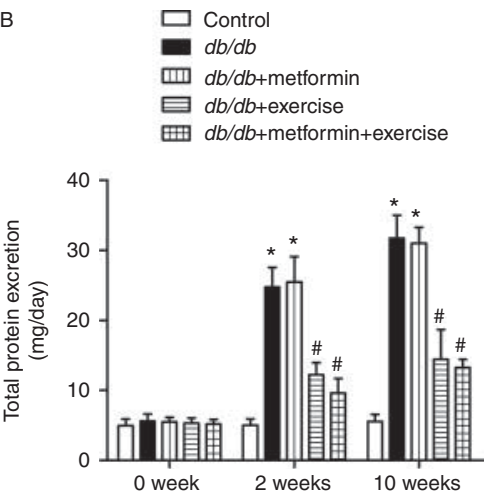

C $\square$ Control

띠 Control+metformin

曰 Control+exercise

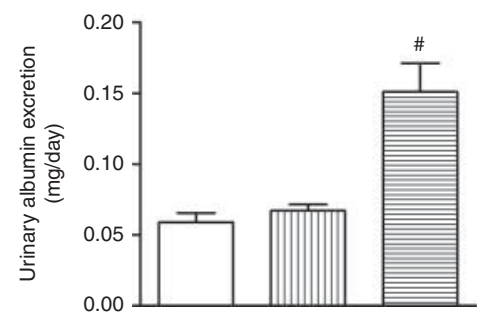

\section{Figure 2}

Effects of exercise training and/or metformin on albuminuria and proteinuria. (A) Repeated measures two-way ANOVA using a Bonferroni's post hoc test showed a significant increase in albuminuria of $d b / d b$ mice at 0,2 , and 10 weeks after the treatment compared with age-matched controls. Similarly, urinary albumin excretion levels of $d b / d b$ mice were significantly increased with age $(* P<0.0001)$. Exercise training alone and in combination with metformin attenuated urinary albumin levels of $d b / d b$ mice throughout the study period, ${ }^{\#} P<0.0001$ vs untreated $d b / d b$ mice, whereas treatment with metformin attenuated albuminuria after 2 weeks of treatment ( ${ }^{\#} P<0.0001$ ) but had no effect at the end of the study. Bars represent mean \pm S.E.M. of group size $(n=10)$. (B) At baseline, no difference was observed in urinary total protein excretion but this was significantly higher 2 and 10 weeks later compared with the results for age-matched control mice $(* P<0.0001)$. Exercise training alone and in combination with metformin attenuated urinary total protein excretion of $d b / d b$ mice throughout the study period, ${ }^{\#} P<0.0001$ vs untreated $d b / d b$ mice, whereas treatment with metformin had no effect at 2 or 10 weeks after the treatment. Bars represent mean \pm S.E.M. of group size $(n=10)$. (C) Urinary albumin excretion of control, control + metformin, and control + exercise mice at 10 weeks of treatment. One-way ANOVA showed a significant increase in urinary albumin excretion of normal mice subjected to exercise training for 10 weeks ${ }^{\#} P<0.0001$. Metformin treatment for 10 weeks had no effect on albumin excretion of normal mice. Bars represent mean \pm s.E.M. of group size $(n=10)$.

Published by Bioscientifica Ltd. 

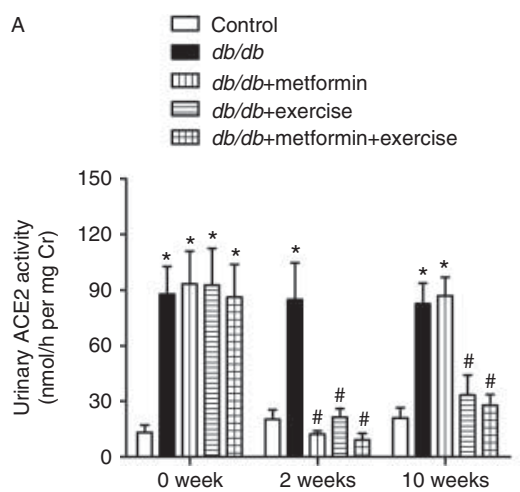

B

\section{$\square$ Contro}

$a b / d b$

U⿴囗⿰丿丨丁 $d b / d b+$ metformin

$\boxminus d b / d b+$ exercise

曲 $d b / d b+$ metformin+exercise

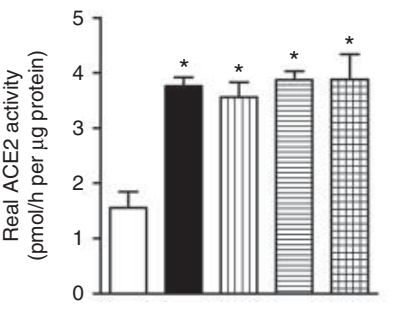

C

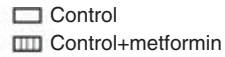

$\boxminus$ Control+exercise

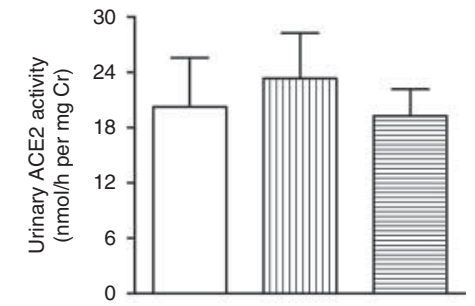

\section{Figure 3}

Effects of exercise training and/or metformin on urinary and renal ACE2 activity. (A) Urinary ACE2 activity of control, treated, and untreated $d b / d b$ mice at 0,2 , and 10 weeks after the commencement of treatment. ACE2 activity was significantly higher in the urine of $d b / d b$ mice compared with age-matched control mice ( $\left.{ }^{*} P<0.0001\right)$. Repeated measures two-way ANOVA showed that exercise training with or without metformin attenuated urinary ACE2 activity of $d b / d b$ mice at 0,2 , and 10 weeks after the commencement of treatment. ${ }^{\#} P<0.0001$ vs untreated $d b / d b$ mice. Metformin was effective in lowering urinary ACE2 activity after 2 weeks of treatment ( $\left.{ }^{\#} P<0.0001\right)$ but had no effect at 10 weeks. Bars represent

to the urinary ACE2 activity, no significant difference was observed in kidney ACE2 activity among the exercise, metformin, and exercise + metformin groups compared with the untreated diabetic group at 17 weeks of age (Fig. 3B). No significant differences were seen between untreated, metformin-treated, and exercise-trained non-diabetic mice.

\section{Effects of exercise and metformin on renal ACE2 protein expression and urinary ACE2 excretion}

As shown in Fig. 4A and D, renal ACE2 was identified by western analysis as a protein of $90 \mathrm{kDa}$. Immunoblot of urinary ACE2 revealed clear, thick, and prominent bands at $\sim 70 \mathrm{kDa}$ in $d b / d b$ mice, which could represent a degradation fragment of ACE2, at 7, 9, and 17 weeks, whereas no bands were observed from non-diabetic mice and $d b / d b$ diabetic mice subjected to exercise alone and in combination with metformin. Metformin treatment attenuated urinary ACE2 excretion of $d b / d b$ mice during the initial 2 weeks of treatment (Fig. 4B) but had no effect at 10 weeks (Fig. $4 \mathrm{C}$ ). In $d b / d b$ mice, kidneys had higher levels of renal ACE2 protein (Fig. 4D). In concordance with activity (see above), we observed no difference in renal ACE2 expression among the control $d b / d b, d b / d b+$ metformin, $d b / d b+$ exercise, and $d b / d b+$ combination groups after the conclusion of the 10-week treatment (Fig. 4D). No significant differences were seen between untreated, metformin-treated, and exercise-trained non-diabetic mice. mean \pm S.E.M. of group size $(n=10)$. (B) Renal ACE2 activity after 10 weeks treatment. Activity of ACE2 in the kidney of $d b / d b$ mice was significantly increased compared with age-matched control mice $(* P<0.0001)$.

No differences were observed in the renal ACE2 activity of metformintreated or exercise-trained $d b / d b$ mice compared with untreated $d b / d b$ mice. Bars represent mean \pm s.E.M. of group size $(n=10)$. (C) Urinary ACE2 excretion of control, control + metformin, and control + exercise mice at 10 weeks of treatment. One-way ANOVA showed no difference in urinary ACE2 excretion of untreated, metformin-treated, and exercise-trained control mice. Bars represent mean \pm S.E.M. of group size $(n=10)$.

Effects of exercise and metformin on renal ADAM17 and tissue inhibitor of metalloproteinase 3 protein expression

As shown in Fig. 4E, renal ADAM17 protein expression was significantly increased in $d b / d b$ diabetic mice compared with their age-matched controls. Exercise training alone and in combination with metformin significantly decreased renal ADAM17 protein expression of $d b / d b$ mice (Fig. $4 \mathrm{E}$ ). Treatment with metformin for 10 weeks had no effect on renal ADAM17 protein levels in $d b / d b$ mice (Fig. 4E). Interestingly, renal tissue inhibitor of metalloproteinase 3 (TIMP3) protein levels were not significantly different in any group after 10 weeks of treatment (Fig. 4F).

\section{Effects of exercise and metformin on kidney histopathology and immunohistochemistry}

PAS-stained kidney sections from $d b / d b$ mice had increased glomerular surface area and expanded mesangial matrix as shown in Fig. 5A. Treatment with metformin alone had no influence on the above alterations, whereas exercise alone and inc combination with metformin reduced glomerular surface area significantly and attenuated mesangial expansion in $d b / d b$ mice (Fig. 5A). Collagen deposition was significantly increased in the kidneys of diabetic $d b / d b$ mice compared with agematched control mice. Exercise training alone and in combination with metformin for 10 weeks was associated

Published by Bioscientifica Ltd. 
A

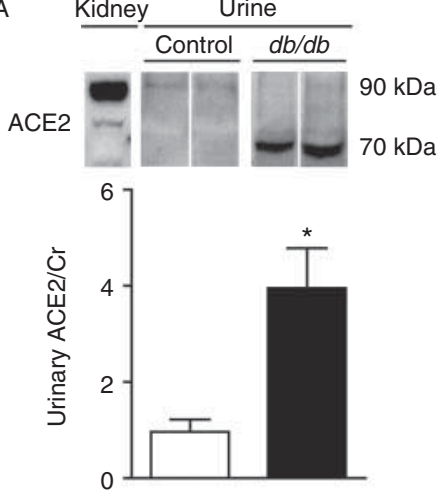

D
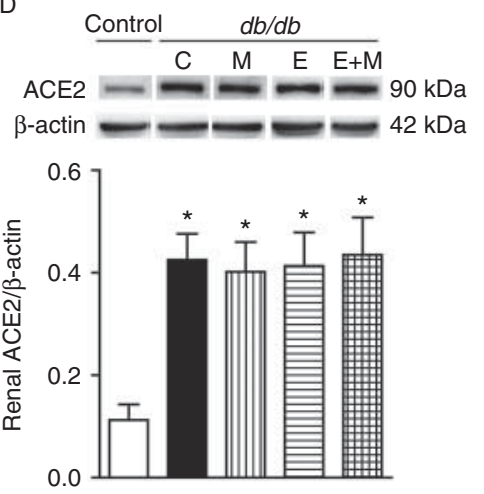

B
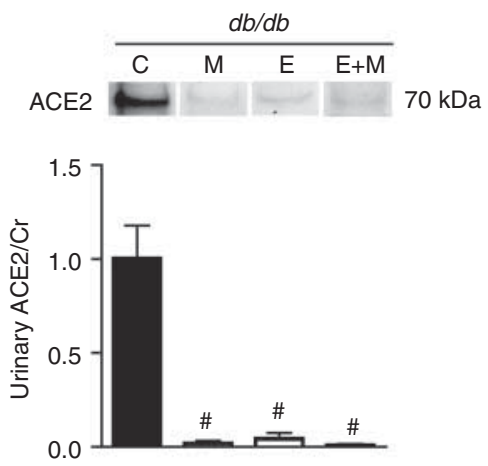

$\mathrm{E}$

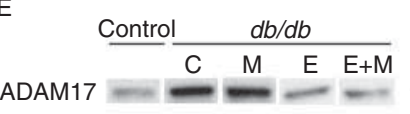

$\beta$-actin $=-\infty$

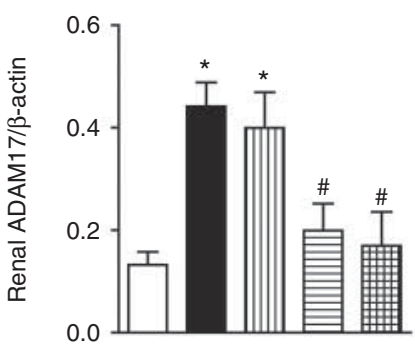

C
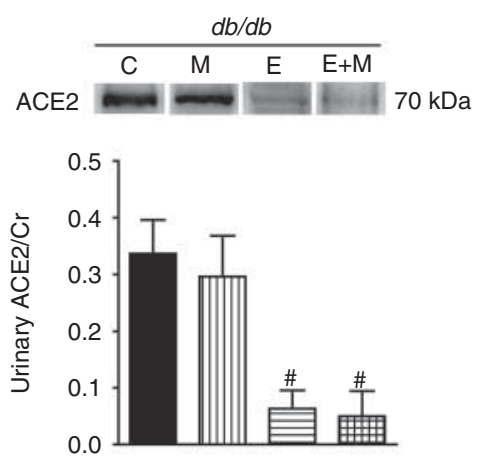

$\mathrm{F}$

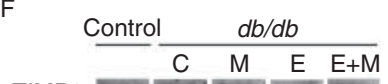

$93 \mathrm{kDa}$ TIMP3 $=30 \mathrm{kDa}$

$42 \mathrm{kDa} \quad \beta$-actin

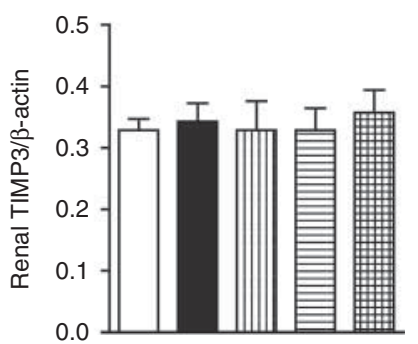

Figure 4

Effects of exercise training and/or metformin on urinary and renal ACE2, ADAM17, and TIMP3 expression. (A) Western blots analyses of ACE2 protein excretion in the urine of normal and $d b / d b$ mice at baseline. Immunoreactive bands for ACE2 were observed at $90 \mathrm{kDa}$ in mouse kidney lysate (lane 1, positive control) and normal urine (lanes 2 and 3 ). However, clear, thick, and prominent bands were seen at $70 \mathrm{kDa}$ in the urine of $d b / \mathrm{db}$ mice (lanes 4 and 5) indicating a degradation fragment of ACE2. There was a significant increase in urinary ACE2 excretion of $d b / d b$ mice compared with age-matched controls $\left({ }^{*} P<0.01\right)$. Bars represent mean \pm s.E.M. of group size $(n=10)$. (B) Western blots analyses of ACE2 protein expression in the urine of $d b / d b$ mice after 2 weeks of treatment. Urinary ACE2 excretion was significantly attenuated in $d b / d b+$ metformin, $d b / d b+$ exercise, and $d b / d b+$ exercise + metformin mice compared with untreated $d b / d b$ mice. ${ }^{\#} P<0.0001$ vs untreated $d b / d b$ mice. Each bar represents mean \pm s.E.M. of group size $(n=10)$. (C) Western blot analysis of ACE2 protein expression in the urine of $d b / d b$ mice after 10 weeks of treatment. Urinary ACE2 excretion was significantly attenuated in $d b / d b$ mice subjected to exercise training with or without metformin for 10 weeks. ${ }^{\#} P<0.0001$ vs untreated $d b / d b$ mice. Alternatively, metformin had no effect on urinary ACE2 protein expression of treated $d b / d b$ mice compared with untreated $d b / d b$ mice. Bars represent mean \pm s.E.M. of group size $(n=10)$. (D) ACE2 protein levels in the kidney of control, treated, and untreated $d b / d b$ mice after the completion of 10 weeks of treatment. One-way ANOVA showed that ACE2 protein expression was significantly increased in $d b / d b$ mice compared with age-matched control mice $\left({ }^{\star} P<0.0001\right)$. There was no significant difference in ACE2 protein expression in treated $d b / d b$ mice compared with untreated $d b / d b$ mice after 10 weeks of treatment. Bars represent mean \pm s.E.M. of group size $(n=9)$. (E) Immunoblot of renal ADAM17 protein levels. One-way ANOVA showed that renal ADAM17 was significantly upregulated in $d b / d b$ mice compared with agematched control mice ( $* P<0.001)$. Exercise training alone and in combination with metformin treatment for 10 weeks, attenuated renal ADAM17 protein levels significantly in treated $d b / d b$ mice compared with untreated $d b / d b$ mice. ${ }^{\#} P<0.0001$ vs untreated $d b / d b$ mice. Treatment with metformin for 10 weeks had no effect on renal ADAM17 protein levels of $d b / d b$ mice. Bars represent mean \pm s.E.M. of group size $(n=9)$. (F) Western blot analysis of renal TIMP3 protein expression. One-way ANOVA showed no differences in the renal TIMP3 protein levels. Bars represent mean \pm s.E.M. of group size $(n=9)$. with significantly reduced collagen deposits (Fig. 5B). This effect was not seen in metformin-treated $d b / d b$ mice. Immunofluorescence of kidney sections showed a significant increase in the renal ADAM17 protein levels of $d b / d b$ mice compared with non-diabetic control mice. Exercise training with or without metformin significantly attenuated renal ADAM17 protein levels, whereas treatment with metformin alone had no effect (Fig. 6A). Expression patterns of ACE2 protein were significantly decreased in glomeruli and increased in tubules of $d b / d b$ mice compared with control mice. Glomerular ACE2 protein was significantly increased in 17 -week-old $d b / d b$ mice subjected to exercise training with or without metformin. However, treatment with metformin alone had no effect on glomerular ACE2 protein expression compared with control $d b / d b$ mice. No significant difference was seen in 

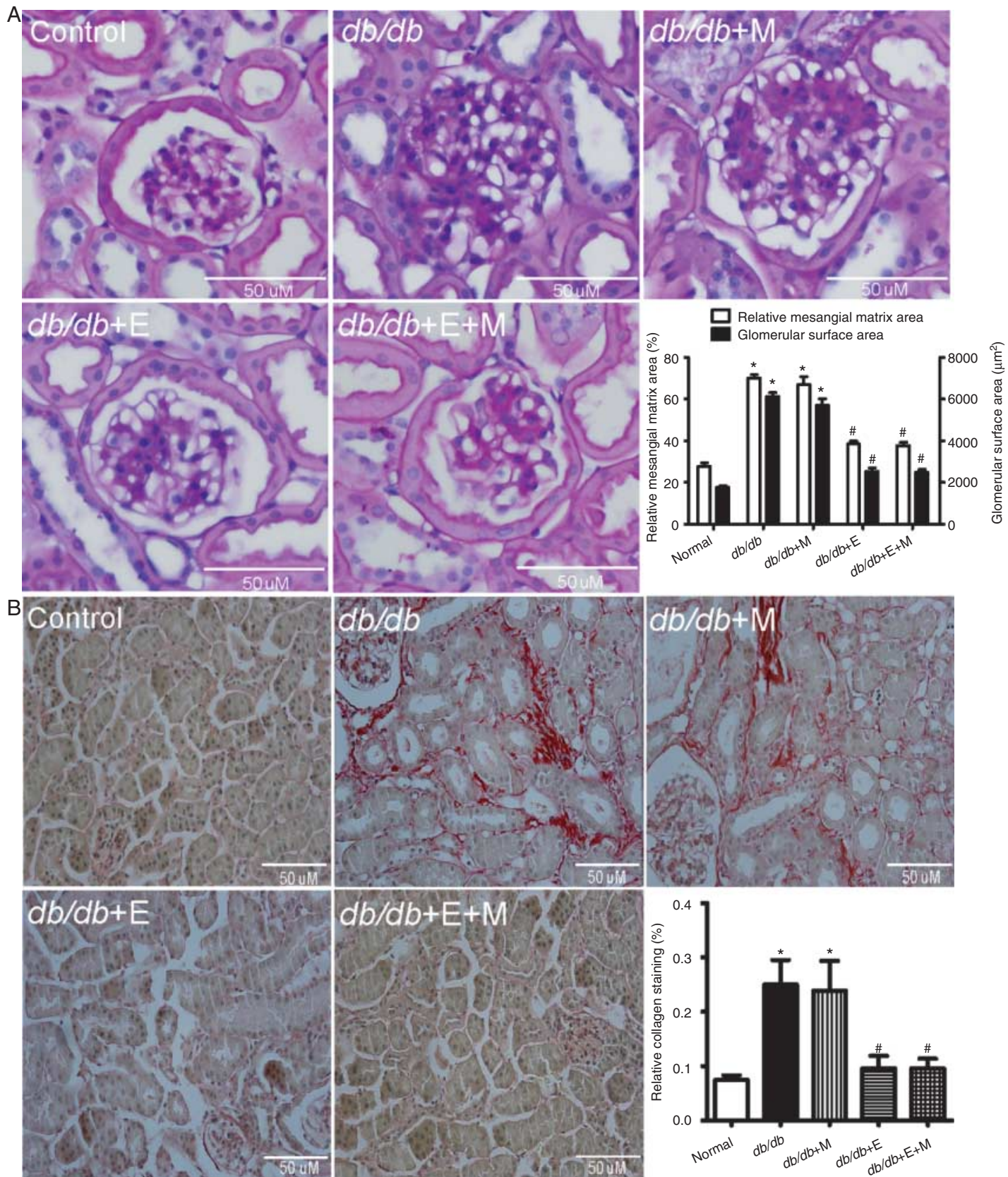

\section{Figure 5}

Effects of exercise training and/or metformin on renal pathology. (A) Representative PAS-stained photomicrographs for control, $d b / d b$, $d b / d b+$ metformin, $d b / d b+$ exercise, and $d b / d b+$ exercise + metformin mice, and graph displaying the magnitude of mesangial and glomerular surface areas. Original magnification: $40 \times$. There was a significant increase in the mesangial matrix and glomerular surface areas of $d b / d b$ diabetic mice compared with age-matched non-diabetic mice, ${ }^{*} P<0.001$. Ten weeks of exercise training alone and in combination with metformin attenuated mesangial matrix expansion and glomerular surface area of treated $\mathrm{db} / \mathrm{db}$ mice compared with untreated $d b / d b$ mice. ${ }^{\#} P<0.0001$ vs control $d b / d b$ mice. In contrast, 10 weeks of treatment with metformin had no effect on the relative mesangial matrix and glomerular surface areas of $d b / d b$ mice. Bars represent mean \pm S.E.M. of group size $(n$, no of glomeruli $=20$ ). Printed in Great Britain
(B) Representative picro-Sirius-stained photomicrographs for control, $d b / d b, d b / d b+$ metformin, $d b / d b+$ exercise, and $d b / d b+$ exercise + metformin mice, and graph displaying the magnitude of collagen deposits. Original magnification: $20 \times$. Collagen deposition was significantly increased in $\mathrm{db} / \mathrm{db}$ diabetic mice compared with age-matched non-diabetic controls. Ten weeks of exercise training alone and in combination with metformin attenuated collagen deposition of treated $\mathrm{db} / \mathrm{db}$ mice compared with untreated $d b / d b$ mice. ${ }^{*} P<0.0001$ for untreated and metformin-treated $d b / d b$ groups vs normal (non-diabetic) mice. ${ }^{\#} P<0.0001$ vs untreated $d b / d b$ mice. In contrast, metformin treatment for 10 weeks had no effect on collagen deposits in $d b / d b$ mice. Bars represent mean \pm s.E.M.

Published by Bioscientifica Ltd. 


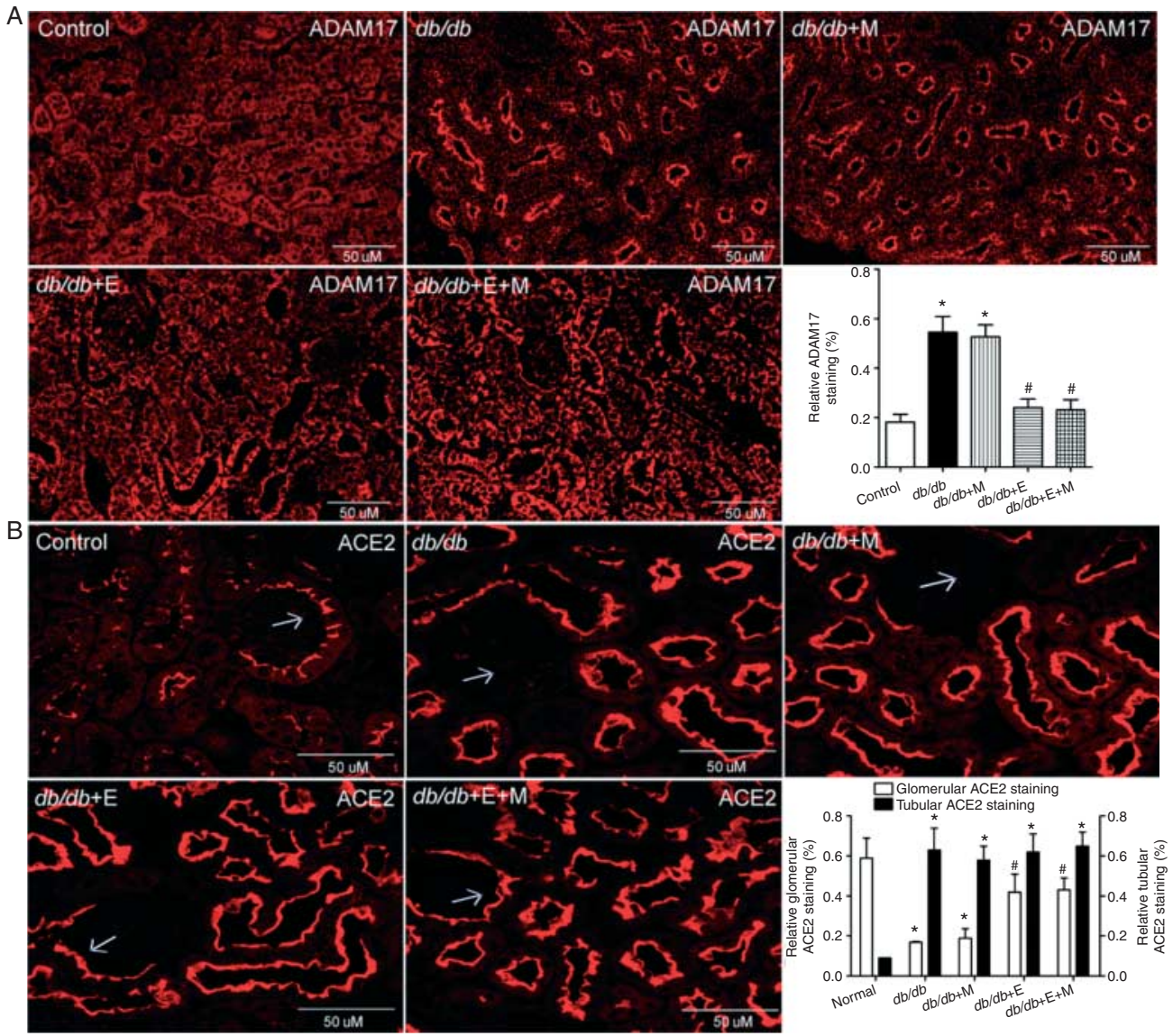

\section{Figure 6}

Effects of exercise training and/or metformin on renal ADAM17 and ACE2 proteins. (A) Representative photomicrographs for control, $d b / d b, d b / d b+$ metformin, $d b / d b+$ exercise, and $d b / d b+$ exercise + metformin mice, and graph displaying staining intensity for ADAM17 protein in the cortex.

Original magnification: $40 \times$. ADAM17 staining was significantly increased in $d b / d b$ mice compared with age-matched control mice, $* P<0.001$.

After the completion of 10 weeks of treatment, staining was significantly decreased in $d b / d b$ mice subjected to exercise training with or without metformin. ${ }^{\#} P<0.001$ vs untreated $d b / d b$ mice. No difference was seen in the intensity of staining for $d b / d b$ mice treated with metformin compared with the untreated $d b / d b$ group. Each bar represents mean \pm s.E.M. of group size. (B) Representative photomicrographs for control, $d b / d b$,

the tubular ACE2 protein expression of untreated $d b / d b$ mice and $d b / d b$ mice subjected to exercise and/or metformin (Fig. 6B). No significant differences were seen between untreated, metformin-treated, and exercisetrained control mice.

\section{Effects of exercise and metformin on plasma hormone and lipid measurement}

Diabetic $d b / d b$ mice displayed higher levels of plasma insulin, glucose, glucagon, and triglycerides and lower levels of adiponectin compared with age-matched $d b / d b+$ metformin, $d b / d b+$ exercise, and $d b / d b+$ exercise + metformin mice, and graph displaying staining intensity for ACE2 protein in the cortex. Original magnification: $60 \times$. Expression of ACE2 protein was significantly decreased in glomeruli (indicated by arrows) and increased in tubules of $d b / d b$ mice compared with controls, $* P<0.001$. Glomerular ACE2 protein (indicated by arrows) was significantly increased in $d b / d b$ mice subjected to exercise training with or without metformin for 10 weeks. ${ }^{\#} P<0.01$ vs untreated $d b / d b$ mice. Treatment with metformin had no effect on glomerular ACE2 protein expression (indicated by arrows) compared with the untreated $d b / d b$ mice. No difference was seen in the tubular ACE2 protein expression of untreated and treated $d b / d b$ mice. Bars represent mean \pm S.E.M. of group size.

controls (Table 1). Exercise training alone and in combination with metformin significantly reduced plasma glucose, and triglycerides, and enhanced plasma insulin levels after 10 weeks of treatment. In contrast, metformin treatment of $d b / d b$ mice significantly enhanced plasma triglyceride levels but resulted in no differences in plasma insulin, glucose, and glucagon compared with untreated $d b / d b$ mice. A combination of exercise training and metformin treatment was effective for lowering plasma glucagon levels (Table 1). No significant differences were seen between untreated, metformin-treated, and exercisetrained non-diabetic mice.

Published by Bioscientifica Ltd. 


\section{Correlation of urinary ACE2 with plasma and urinary risk factors in diabetes}

To investigate the potential of urinary ACE2 as a risk marker in type 2 diabetes, it was correlated with albuminuria, blood glucose, plasma insulin, glucagon, and triglycerides from control non-diabetic, control $d b / d b$ and $d b / d b$ mice subjected to exercise and/or metformin. Urinary ACE2 was significantly and positively correlated with albuminuria, blood glucose, plasma glucagon, and triglycerides. In addition, urinary ACE2 excretion was negatively associated with plasma insulin levels (Fig. 7).

\section{Discussion}

The current study investigated the effects of exercise training on glucose homeostasis and renal alterations in $d b / d b$ type 2 diabetic mice. Although several studies have validated the beneficial effects of exercise with or without diet restriction on diabetes (Pan et al. 1997, Tuomilehto et al. 2001, Knowler et al. 2002, Fradkin et al. 2012), effects of these interventions on the complications associated with diabetes have not been extensively investigated. In addition, mechanisms underlying the positive effects of exercise on glucose homeostasis remain poorly understood. Both physical exercise and metformin are first-line interventions for the management of type 2 diabetes. We thus investigated their effects on glucose homeostasis, albuminuria, renal ADAM17, ACE2 shedding, and renal pathology.

At 7 weeks, $d b / d b$ mice excreted higher levels of albumin and ACE2 in the urine, but no differences were observed in their urinary total protein excretion levels. The observed discrepancy between urinary albumin and protein excretion
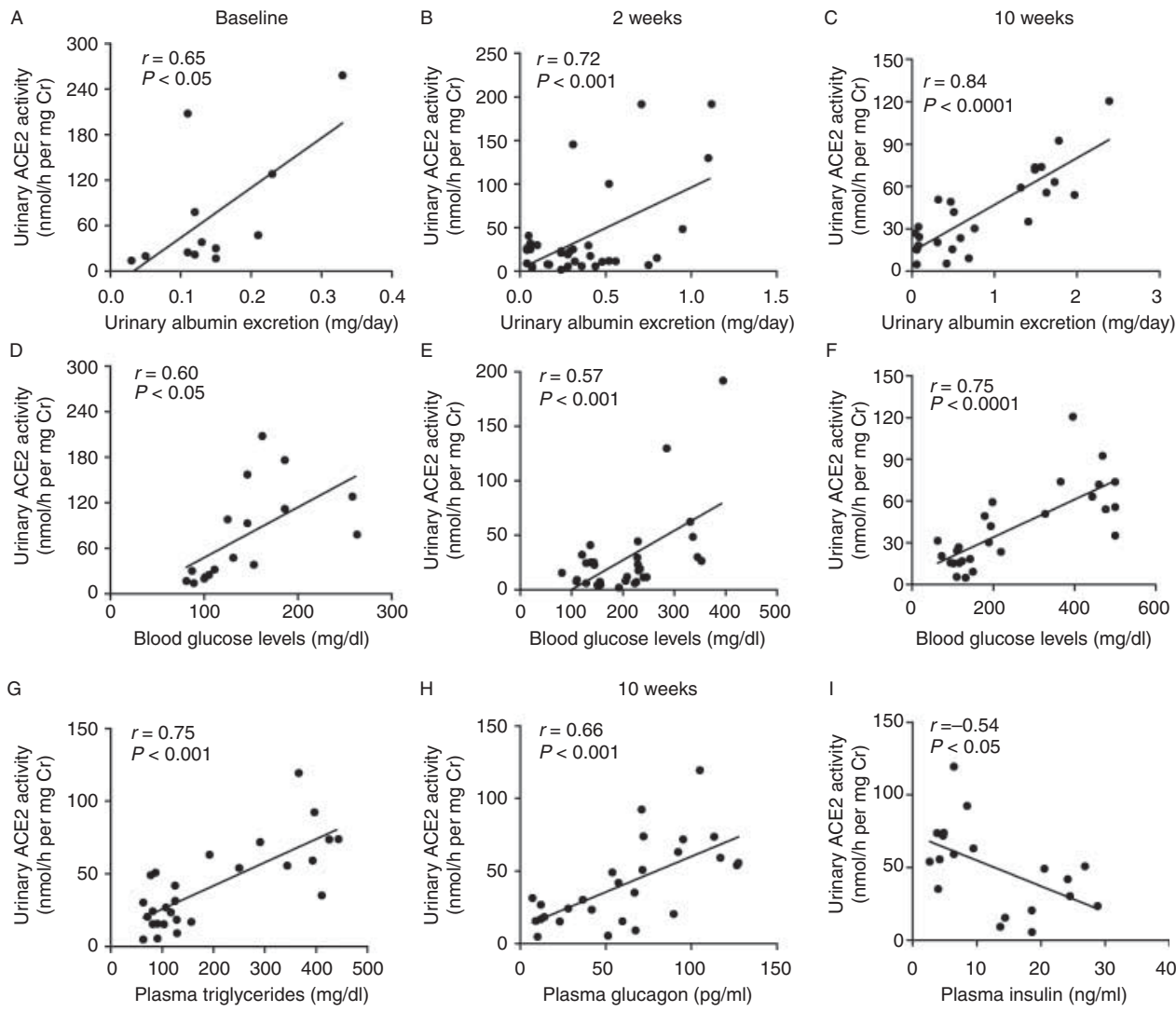

\section{Figure 7}

Correlation between urinary ACE2 activity and urinary albumin, blood glucose, plasma glucagon, triglycerides, and insulin levels. Shown are comparisons with significant correlations. Association of urinary ACE2 activity and albumin excretion in control mice, $d b / d b$ mice, and $d b / d b$ mice subjected to exercise and/or metformin at (A) baseline, (B) 2 weeks, and (C) 10 weeks after commencement of treatment. Correlation between urinary ACE2 activity and blood glucose levels in control mice, $\mathrm{db} / \mathrm{db}$ mice, and $d b / d b$ mice subjected to exercise and/or metformin at (D) baseline,
(E) 2 weeks, and (F) 10 weeks after the commencement of treatment. (G) Correlation between urinary ACE2 and plasma triglycerides in normal mice, $d b / d b$ mice, and $d b / d b$ mice subjected to exercise and/or metformin at 10 weeks. $(\mathrm{H})$ Correlation between urinary ACE2 and plasma glucagon concentrations in normal mice, $d b / d b$ mice, and $d b / d b$ mice subjected to exercise and/or metformin at 10 weeks. (I) Correlation between urinary ACE2, and plasma insulin levels in normal, $d b / d b$, and $d b / d b$ mice subjected to exercise and/or metformin at 10 weeks ( $n=9$ per group). http://joe.endocrinology-journals.org DOI: 10.1530/JOE-13-0532
(C) 2014 Society for Endocrinology Printed in Great Britain
Published by Bioscientifica Ltd 
is in line with the results of a previous study conducted in streptozotocin diabetic rats (Palm et al. 2004). Our results demonstrated a strong association between urinary albumin and ACE2. Increased albumin, ACE2 protein, and activity in the urine of $d b / d b$ diabetic mice correspond to those for diabetic patients (Mizuiri et al. 2011, Xiao et al. 2012), indicating that the syndrome of diabetic nephropathy in the $d b / d b$ mouse model could reflect human diabetic nephropathy. Albuminuria is an indication of glomerular damage (Ye et al. 2006) and urinary ACE2 is a reflection of tubular damage (Chodavarapu et al. 2013, Wysocki et al. 2013). Even though mechanisms responsible for urinary albumin and ACE2 contrast with each other, we correlated urinary ACE2 with albuminuria to explore its potential use as a marker of renal injury. We showed a strong correlation of ACE2 and albuminuria. Future analysis to determine whether ACE2 is excreted prior to albuminuria would be necessary to determine whether it could be used in an alternative procedure for early detection of renal disease associated with diabetes (Lee 2005). This is especially important because recent clinical studies questioned the reliability of albuminuria for anticipating the progression and prevention of end-stage renal disease (de Galan et al. 2009, Rocco \& Berns 2012). In addition, non-diabetic mice subjected to physical exercise show significantly higher levels of urinary albumin with no differences in their blood glucose and renal morphology. These data call into question the specificity of albuminuria as a sensitive marker for kidney disease.

Exercise with or without metformin significantly lowered blood glucose levels consistently and improved glucose tolerance of $d b / d b$ mice. The blood-glucoselowering effect of exercise was seen as early as 1 week after the initiation of treatment. In comparison, metformin treatment was effective at lowering hyperglycemia in the early stages of diabetes but failed with the progression of disease severity in later stages. Exercise-mediated improvements in glucose homeostasis could, at least partially, be attributed to the elevated plasma insulin levels. Even though many studies have proposed a hyperbolic relationship between insulin secretion and insulin action, there has always been a discrepancy in the relative importance of decreased insulin sensitivity and insulin secretion in the pathogenesis of type 2 diabetes. Individuals with diabetes manifest progressive deterioration of both insulin action and insulin secretion (Weyer et al. 1999) and it has been suggested that interventions should target both insulin abnormalities to prevent diabetes or to achieve maximal therapeutic benefits (Weyer et al. 1999, Kitabchi et al. 2005). In the current study, apart from improved glucose levels and glucose tolerance, exercise training increased plasma insulin levels by almost threefold in $d b / d b$ mice. This twofold to threefold rise in insulin levels of exercise trained $d b / d b$ mice is in agreement with the results from previous reports (Tang \& Reed 2001, Sennott et al. 2008). One explanation could be that exercise preserves the integrity of the pancreatic $\beta$ cells and hence preserves their insulin secretory capacity (Tang \& Reed 2001). Furthermore, we also speculate that the $\beta$ cells from exercise-trained $d b / d b$ mice were adapted with enhanced insulin secretion after being subjected to moderate-intensity training for a long duration of 10 weeks in order to achieve maximum therapeutic benefits. Although type 2 diabetes is characterized by hyperinsulinemia, enhanced insulin levels may not be sufficient to overcome the tissue resistance to insulin. Based on our findings, we speculate that a further increase in the plasma insulin levels during exercise training could be able to counteract the resistance exhibited by various tissues and it could be one of the mechanisms behind improved glycemic control in exercised $d b / d b$ mice. In contrast to our observation, a study conducted on type 2 diabetic subjects reported decreased blood glucose and plasma insulin levels with exercise (Musi et al. 2001), which could be explained by increased insulin sensitivity. Insulin sensitivity can be enhanced by changing body composition (Yki-Jarvinen \& Koivisto 1983), stimulating muscle blood flow (Yki-Jarvinen \& Koivisto 1983) or GLUT4 protein levels (Yki-Jarvinen \& Koivisto 1983, Rodnick et al. 1990). We noticed no differences in body composition between exercised and sedentary diabetic and non-diabetic mice. However, we cannot rule out the possibility of enhanced insulin-mediated GLUT4 translocation from an intracellular pool to the plasma membrane of muscle and AMPK $\alpha 2$ activation in exercised diabetic mice (Hughes et al. 1993, Ivy 1997, Musi et al. 2001, 2002, Scarpello \& Howlett 2008). These improvements in exercised $d b / d b$ mice were not associated with changes in body weight or fat percentage despite the lower food intake and presumably higher energy consumption. This could be explained from the recent findings, where exercise has been shown to increase plasma irisin levels (Bostrom et al. 2012) and to induce browning, both of which are accompanied by an increase in energy expenditure (Castillo-Quan 2012). Although we did not measure the white and brown fat content in our mice, we speculate that more of the white adipose tissue is converted to calorie burning, metabolically active brown adipose tissue in exercise-trained mice (Castillo-Quan 2012). As there are only a few studies that observed beneficial effects of physical activity alone without diet modifications (to lose weight) in diabetes, findings from our study highlight the

Published by Bioscientifica Ltd. 
notion that physical exercise alone can be effective in managing type 2 diabetes. This is in turn supported by a randomized clinical trial conducted on individuals with impaired glucose tolerance (Pan et al. 1997).

Exercise alone and in combination with metformin was consistently effective in attenuating albuminuria, reducing renal pathology, and attenuating ACE2 excretion. This reflects its positive effects against diabetic nephropathy, which is considered to be one of the major microvascular complications of diabetes (Kohzuki et al. 2001, Tufescu et al. 2008, Ishikawa et al. 2012). Improvements in albuminuria and ACE2 excretion were seen as early as 2 weeks after the initiation of treatment. To our knowledge, this is the first report showing that amelioration of kidney damage during exercise training is associated with a significant decrease in urinary ACE2 excretion. Interestingly, exerciseinduced albuminuria/proteinuria is often reported in normal as well as in diabetic human subjects (Heathcote et al. 2009, Koh etal. 2011, Kornhauser et al. 2012). This may be attributed to the intensity and duration of the exercise (Saeed et al. 2012). In agreement with results from previous reports (Ghosh et al. 2009), physical exercise training reduced mesangial expansion and glomerular surface area of $d b / d b$ mice. Reduced glomerular and tubular basement membrane thickening and attenuation of glomerular and tubular collagen deposits by exercise indicates that the beneficial effect of exercise in renal injury is accompanied by the improvements in both glomerular and tubular pathologies in $d b / d b$ mice.

In our previous study, we reported that renal injury in $d b / d b$ mice was associated with enhanced renal ADAM17 protein-mediated shedding of ACE2 (Chodavarapu et al. 2013). This assertion has been, at least partially, evaluated in human subjects, demonstrating increased renal ADAM17 protein levels in human renal disease (Melenhorst et al. 2009). In fact, upregulation of ADAM17 protein in $d b / d b$ diabetic kidneys was reversed by exercise training. This is the first study, to our knowledge, reporting the effect of physical exercise on ADAM17, a metalloproteinase that is implicated in many chronic diseases (White 2003, Kaneko et al. 2011). Although it has been reported that ADAM17 is predominantly localized to distal renal tubules (Lautrette et al. 2005), our results showed strong staining in both proximal and distal cortical tubules and glomeruli but not in the medulla of $d b / d b$ mice. This discrepancy may be due to differences in the species, age, or the severity of the disease.

As we reported earlier, ACE2 in the urine of $d b / d b$ diabetic mice originates from the kidney (Chodavarapu et al. 2013) and this was also supported by a recent study (Wysocki et al. 2013). In spite of some reports suggesting decreased renal ACE2 in diabetes (Tikellis et al. 2003, Reich et al. 2008), our previous studies showed a significant increase in renal ACE2 protein expression in $d b / d b$ mice (Chodavarapu et al. 2013). Plasma ACE activity and Ang II content were high in 8-week-old $d b / d b$ mice compared with control mice (Senador et al. 2009), and this indicates that the deleterious renal effects of Ang II are counterregulated by upregulating ACE2. We have previously shown that renal ACE2 activity of 8-week-old $d b / d b$ mice is significantly higher than that of 31-week-old $d b / d b$ mice. Based on these observations, we speculate that, with progression of the disease (age), the kidney is unable to maintain ACE2 levels due to escalating ADAM17 protein. As a consequence of increased renal ADAM17 protein and shedding of ACE2, $d b / d b$ mice had a significantly increased glomerular surface area, glomerular and tubular basement membrane thickening, expanded mesangial matrix, and collagen deposits. As ACE2 is considered to be renoprotective, ADAM17-induced shedding of ACE2 is an important contributor to the pathogenesis of diabetic nephropathy. Based on all these considerations, it is tempting to speculate that attenuation of ADAM17 by exercise training in the kidney of $d b / d b$ mice, which is responsible for attenuating ACE2 shedding into urine, could be considered to be a renoprotective mechanism. Further evidence of the effect of ADAM17 is in the absence of an effect of metformin on renal disease. Administration of metformin did not attenuate renal ADAM17 and ACE2 shedding and had no effect on the renal pathologies of diabetic mice. However, considering albuminuria and urinary ACE2 as risk markers of diabetic nephropathy, we might presume that metformin treatment could have beneficial actions on diabetic renal pathologies during the initial stages. This novel finding is in agreement with the recent report from Diabetes Prevention Program Outcomes Study demonstrating that lifestyle interventions were effective in reducing the incidence of diabetes by $71 \%$ in human subjects with an age of 60 years, whereas administration of metformin exerted no effects. However, treatment with metformin had beneficial effects in participants of 25-44 years old (Fradkin et al. 2012). The unaltered levels of expression and activity of renal ACE2 between control, metformin-treated, and exercise-trained diabetic $d b / d b$ mice need further investigation.

Previously, it has been shown that excitation of several cell signaling pathways results in dimeric to monomeric shift of ADAM17. This is associated with increased ADAM17 and decreased TIMP3, indicating that TIMP3 is an endogenous inhibitor of ADAM17 (Xu et al. 2012). A recent study

Published by Bioscientifica Ltd 
reported that deficiency of TIMP3 results in increased ADAM17 activity, exacerbating diabetic nephropathy in Akita type 1 diabetic mice (Basu et al. 2012). In contrast to these findings, we observed no differences in renal TIMP3 protein levels among non-diabetic and diabetic $d b / d b$ mice, highlighting the involvement of different mechanisms in the activation of ADAM17 in types 1 and 2 diabetes. However, based on the recent findings (Lautrette et al. 2005, Ford et al. 2013), hyperglycemia and activated Ang II could be the possible reasons for the increased levels of activated ADAM17 protein in the kidneys of $d b / d b$ mice.

In addition to its positive effects on glucose homeostasis and renal pathologies, physical exercise training exerted beneficial actions on metabolic abnormalities associated with type 2 diabetes. Plasma analysis showed significantly increased levels of plasma glucose, glucagon, and triglycerides and decreased levels of adiponectin in $d b / d b$ mice compared with controls. However, physical exercise training significantly attenuated plasma glucose and triglyceride levels of $d b / d b$ mice. Previously, exercise training has been shown to improve renal function of CKD patients by lowering plasma triglycerides, at least partially (Toyama et al. 2010). Metformin had no effect on plasma glucose, glucagon, insulin, or adiponectin. In fact, metformin treatment was associated with a significant increase in triglyceride levels of $d b / d b$ mice, which, in contrast, has been shown to attenuate plasma triglyceride levels in rodent models as well as in type 2 diabetic patients (Wulffele et al. 2004, Tessari \& Tiengo 2008). A combination of physical exercise training and metformin significantly decreased the plasma glucagon concentrations. Furthermore, we correlated these plasma risk factors with urinary ACE2 excretion to strengthen our notion of using urinary ACE2 as a surrogate marker for diabetes.

In summary, 7 -week-old type 2 diabetic $d b / d b$ mice developed hyperglycemia and excreted greater amounts of urinary albumin and ACE2. The presence of ACE2 in the urine of diabetic mice is a consequence of tubular damage that is associated with the sheddase activity of ADAM17 in the kidney (Chodavarapu et al. 2013, Salem et al. 2014). Loss of the renoprotectant, ACE2 into urine is associated with renal injury in diabetic mice. Exercise training significantly decreased renal ADAM17 protein levels and ameliorated renal pathologies in trained $d b / d b$ mice compared with control $d b / d b$ mice throughout the study. In contrast, metformin was effective in the initial stages of diabetes and had no effect in the later stages where the disease progress is more severe. Indeed, administration of metformin for 10 weeks had no effect on the albuminuria, renal ADAM17 protein, and shedding of ACE2. As exercise training has been shown to exert pronounced effects in type 2 diabetes and associated complications, with no compromising side effects, physical training programs should be widely adopted into the medical care system. In addition, urinary ACE 2 could be used as a biomarker for diabetic kidney disease and as a screening tool for assessing the effectiveness of therapeutic interventions.

\section{Declaration of interest}

The authors declare that there is no conflict of interest that could be perceived as prejudicing the impartiality of the research reported.

\section{Funding}

This work was supported by the American Heart Association grant SDG 0735112N (K M E), Boonshoft School of Medicine Emerging Science Seed Grant (K M E), the American Orthopaedic Foot and Ankle Society (G P B) and National Institutes of Health Grant R01 HL093567 (K M E).

\section{References}

Amador-Licona N, Guizar-Mendoza J, Vargas E, Sanchez-Camargo G \& Zamora-Mata L 2000 The short-term effect of a switch from glibenclamide to metformin on blood pressure and microalbuminuria in patients with type 2 diabetes mellitus. Archives of Medical Research 31 571-575. (doi:10.1016/S0188-4409(00)00241-1)

American Diabetes Association 2013 Executive summary: standards of medical care in diabetes - 2013. Diabetes Care 36 S4-S10. (doi:10.2337/ dc13-S004)

Arakawa K 1993 Antihypertensive mechanism of exercise. Journal of Hypertension 11 223-229. (doi:10.1097/00004872-199303000-00001)

Basu R, Lee J, Wang Z, Patel VB, Fan D, Das SK, Liu GC, John R, Scholey JW, Oudit GY et al. 2012 Loss of TIMP3 selectively exacerbates diabetic nephropathy. American Journal of Physiology. Renal Physiology 303 F1341-F1352. (doi:10.1152/ajprenal.00349.2012)

Boor P, Celec P, Behuliak M, Grancic P, Kebis A, Kukan M, Pronayova N, Liptaj T, Ostendorf T \& Sebekova K 2009 Regular moderate exercise reduces advanced glycation and ameliorates early diabetic nephropathy in obese Zucker rats. Metabolism 58 1669-1677. (doi:10.1016/ j.metabol.2009.05.025)

Bostrom P, Wu J, Jedrychowski MP, Korde A, Ye L, Lo JC, Rasbach KA, Bostrom EA, Choi JH, Long JZ et al. 2012 A PGC1- $\alpha$-dependent myokine that drives brown-fat-like development of white fat and thermogenesis. Nature 481 463-468. (doi:10.1038/nature10777)

Castillo-Quan JI 2012 From white to brown fat through the PGC-1 $\alpha$ dependent myokine irisin: implications for diabetes and obesity. Disease Models \& Mechanisms 5 293-295. (doi:10.1242/dmm.009894)

Chappell MC 2013 Of diabetic mice and ACE2: a new biomarker of renal disease? American Journal of Physiology. Renal Physiology 305 F970-F972. (doi:10.1152/ajprenal.00403.2013)

Chodavarapu H, Grobe N, Somineni HK, Salem ES, Madhu M \& Elased KM 2013 Rosiglitazone treatment of type 2 diabetic $d b / d b$ mice attenuates urinary albumin and angiotensin converting enzyme 2 excretion. PLOS ONE 8 e62833. (doi:10.1371/journal.pone.0062833)

Ciampone S, Borges R, de Lima IP, Mesquita FF, Cambiucci EC \& Gontijo JA 2011 Long-term exercise attenuates blood pressure responsiveness and modulates kidney angiotensin II signalling and urinary sodium excretion in SHR. Journal of the Renin-Angiotensin-Aldosterone System 12 394-403. (doi:10.1177/1470320311408750) 
Colbert LH, Visser M, Simonsick EM, Tracy RP, Newman AB, Kritchevsky SB, Pahor M, Taaffe DR, Brach J, Rubin S et al. 2004 Physical activity, exercise, and inflammatory markers in older adults: findings from the Health, Aging and Body Composition Study. Journal of the American Geriatrics Society 52 1098-1104. (doi:10.1111/j.1532-5415.2004.52307.x)

Cunha TS, Ap Ronchi F, Sakata MM, Arita DY, Colucci JA, Perez JD, De Angelis K, Marcondes FK, Irigoyen MC \& Casarini DE 2010 Exercise training reduces kidney angiotensin II levels and attenuates renal dysfunction in animal diabetic nephropathy. Diabetes 59 A30-A31.

Federici M, Hribal ML, Menghini R, Kanno H, Marchetti V, Porzio O, Sunnarborg SW, Rizza S, Serino M, Cunsolo V et al. 2005 Timp3 deficiency in insulin receptor-haploinsufficient mice promotes diabetes and vascular inflammation via increased TNF- $\alpha$. Journal of Clinical Investigation 115 3494-3505. (doi:10.1172/JCI26052)

Fernandes T, Hashimoto NY, Magalhaes FC, Fernandes FB, Casarini DE, Carmona AK, Krieger JE, Phillips MI \& Oliveira EM 2011 Aerobic exercise training-induced left ventricular hypertrophy involves regulatory microRNAs, decreased angiotensin-converting enzymeangiotensin II, and synergistic regulation of angiotensin-converting enzyme 2-angiotensin (1-7). Hypertension 58 182-189. (doi:10.1161/ HYPERTENSIONAHA.110.168252)

Ford BM, Eid AA, Göoz M, Barnes JL, Gorin YC \& Abboud HE 2013 ADAM17 mediates Nox4 expression and NADPH oxidase activity in the kidney cortex of OVE26 mice. American Journal of Physiology. Renal Physiology 305 F323-F332. (doi:10.1152/ajprenal.00522.2012)

Fradkin JE, Roberts BT \& Rodgers GP 2012 What's preventing us from preventing type 2 diabetes? New England Journal of Medicine 367 1177-1179. (doi:10.1056/NEJMp1208169)

de Galan BE, Perkovic V, Ninomiya T, Pillai A, Patel A, Cass A, Neal B, Poulter N, Harrap S, Mogensen CE et al. 2009 Lowering blood pressure reduces renal events in type 2 diabetes. Journal of the American Society of Nephrology 20 883-892. (doi:10.1681/ASN.2008070667)

Ghosh S, Khazaei M, Moien-Afshari F, Ang LS, Granville DJ, Verchere CB, Dunn SR, McCue P, Mizisin A, Sharma K et al. 2009 Moderate exercise attenuates caspase- 3 activity, oxidative stress, and inhibits progression of diabetic renal disease in $d b / d b$ mice. American Journal of Physiology. Renal Physiology 296 F700-F708. (doi:10.1152/ajprenal.90548.2008)

Heathcote KL, Wilson MP, Quest DW \& Wilson TW 2009 Prevalence and duration of exercise induced albuminuria in healthy people. Clinical and Investigative Medicine 32 E261-E265.

Hughes VA, Fiatarone MA, Fielding RA, Kahn BB, Ferrara CM, Shepherd P, Fisher EC, Wolfe RR, Elahi D \& Evans WJ 1993 Exercise increases muscle GLUT-4 levels and insulin action in subjects with impaired glucose tolerance. American Journal of Physiology 264 E855-E862.

Hummel KP, Dickie MM \& Coleman DL 1966 Diabetes, a new mutation in the mouse. Science 153 1127-1128. (doi:10.1126/science.153.3740.1127)

Ishikawa Y, Gohda T, Tanimoto M, Omote K, Furukawa M, Yamaguchi S, Murakoshi M, Hagiwara S, Horikoshi S, Funabiki K et al. 2012 Effect of exercise on kidney function, oxidative stress, and inflammation in type 2 diabetic KK-A $\mathrm{A}^{\mathrm{y}}$ mice. Experimental Diabetes Research 2012 702948. (doi:10.1155/2012/702948)

Ivy JL 1997 Role of exercise training in the prevention and treatment of insulin resistance and non-insulin-dependent diabetes mellitus. Sports Medicine 24 321-336. (doi:10.2165/00007256-199724050-00004)

Kaneko H, Anzai T, Horiuchi K, Morimoto K, Anzai A, Nagai T, Sugano Y, Maekawa Y, Itoh H, Yoshikawa T et al. 2011 Tumor necrosis factor- $\alpha$ converting enzyme inactivation ameliorates high-fat diet-induced insulin resistance and altered energy homeostasis. Circulation Journal $\mathbf{7 5}$ 2482-2490. (doi:10.1253/circj.CJ-11-0182)

Kitabchi AE, Temprosa M, Knowler WC, Kahn SE, Fowler SE, Haffner SM, Andres R, Saudek C, Edelstein SL, Arakaki R et al. 2005 Role of insulin secretion and sensitivity in the evolution of type 2 diabetes in the diabetes prevention program: effects of lifestyle intervention and metformin. Diabetes 54 2404-2414. (doi:10.2337/diabetes.54.8.2404)

Knowler WC, Barrett-Connor E, Fowler SE, Hamman RF, Lachin JM, Walker EA $\&$ Nathan DM 2002 Reduction in the incidence of type 2 diabetes with lifestyle intervention or metformin. New England Journal of Medicine 346 393-403. (doi:10.1056/NEJMoa012512)

Koh KH, Dayanath B, Doery JC, Polkinghorne KR, Teede H \& Kerr PG 2011 Effect of exercise on albuminuria in people with diabetes. Nephrology 16 704-709. (doi:10.1111/j.1440-1797.2011.01508.x)

Kohzuki M, Kamimoto M, Wu XM, Xu HL, Kawamura T, Mori N, Nagasaka M, Kurosawa H, Minami N, Kanazawa M et al. 2001 Renal protective effects of chronic exercise and antihypertensive therapy in hypertensive rats with chronic renal failure. Journal of Hypertension 19 1877-1882. (doi:10.1097/00004872-200110000-00024)

Kornhauser C, Malacara JM, Macias-Cervantes MH \& Rivera-Cisneros AE 2012 Effect of exercise intensity on albuminuria in adolescents with type 1 diabetes mellitus. Diabetic Medicine 29 70-73. (doi:10.1111/j. 1464-5491.2011.03380.x)

Lambert DW, Yarski M, Warner FJ, Thornhill P, Parkin ET, Smith AI, Hooper NM \& Turner AJ 2005 Tumor necrosis factor- $\alpha$ convertase (ADAM17) mediates regulated ectodomain shedding of the severeacute respiratory syndrome-coronavirus (SARS-CoV) receptor, angiotensin-converting enzyme-2 (ACE2). Journal of Biological Chemistry 280 30113-30119. (doi:10.1074/jbc.M505111200)

Lautrette A, Li S, Alili R, Sunnarborg SW, Burtin M, Lee DC, Friedlander G \& Terzi F 2005 Angiotensin II and EGF receptor cross-talk in chronic kidney diseases: a new therapeutic approach. Nature Medicine $\mathbf{1 1}$ 867-874. (doi:10.1038/nm1275)

Lee GS 2005 Retarding the progression of diabetic nephropathy in type 2 diabetes mellitus: focus on hypertension and proteinuria. Annals of the Academy of Medicine, Singapore 34 24-30.

Lindstrom J, Ilanne-Parikka P, Peltonen M, Aunola S, Eriksson JG, Hemio K, Hamalainen H, Harkonen P, Keinanen-Kiukaanniemi S, Laakso M et al. 2006 Sustained reduction in the incidence of type 2 diabetes by lifestyle intervention: follow-up of the Finnish Diabetes Prevention Study. Lancet 368 1673-1679. (doi:10.1016/S0140-6736(06)69701-8)

Melenhorst WB, Visser L, Timmer A, van den Heuvel MC, Stegeman CA \& van Goor H 2009 ADAM17 upregulation in human renal disease: a role in modulating TGF- $\alpha$ availability? American Journal of Physiology. Renal Physiology 297 F781-F790. (doi:10.1152/ajprenal.90610.2008)

Mizuiri S, Aoki T, Hemmi H, Arita M, Sakai K \& Aikawa A 2011 Urinary angiotensin-converting enzyme 2 in patients with CKD. Nephrology 16 567-572. (doi:10.1111/j.1440-1797.2011.01467.x)

Musi N, Fujii N, Hirshman MF, Ekberg I, Froberg S, Ljungqvist O, Thorell A \& Goodyear LJ 2001 AMP-activated protein kinase (AMPK) is activated in muscle of subjects with type 2 diabetes during exercise. Diabetes $\mathbf{5 0}$ 921-927. (doi:10.2337/diabetes.50.5.921)

Musi N, Hirshman MF, Nygren J, Svanfeldt M, Bavenholm P, Rooyackers O, Zhou G, Williamson JM, Ljunqvist O, Efendic S et al. 2002 Metformin increases AMP-activated protein kinase activity in skeletal muscle of subjects with type 2 diabetes. Diabetes 51 2074-2081. (doi:10.2337/ diabetes.51.7.2074)

Nathan DM, Buse JB, Davidson MB, Ferrannini E, Holman RR, Sherwin R \& Zinman B 2009 Medical management of hyperglycemia in type 2 diabetes: a consensus algorithm for the initiation and adjustment of therapy: a consensus statement of the American Diabetes Association and the European Association for the Study of Diabetes. Diabetes Care 32 193-203. (doi:10.2337/dc08-9025)

Palm F, Ortsater H, Hansell P, Liss P \& Carlsson PO 2004 Differentiating between effects of streptozotocin per se and subsequent hyperglycemia on renal function and metabolism in the streptozotocin-diabetic rat model. Diabetes/Metabolism Research and Reviews 20 452-459. (doi:10.1002/dmrr.472)

Pan XR, Li GW, Hu YH, Wang JX, Yang WY, An ZX, Hu ZX, Lin J, Xiao JZ, Cao HB et al. 1997 Effects of diet and exercise in preventing NIDDM in people with impaired glucose tolerance. The Da Qing IGT and Diabetes Study. Diabetes Care 20 537-544. (doi:10.2337/diacare.20.4.537)

Pechter U, Ots M, Mesikepp S, Zilmer K, Kullissaar T, Vihalemm T, Zilmer M \& Maaroos J 2003 Beneficial effects of water-based exercise in patients 
with chronic kidney disease. International Journal of Rehabilitation Research 26 153-156. (doi:10.1097/00004356-200306000-00013)

Pereira MG, Ferreira JC, Bueno CR Jr, Mattos KC, Rosa KT, Irigoyen MC, Oliveira EM, Krieger JE \& Brum PC 2009 Exercise training reduces cardiac angiotensin II levels and prevents cardiac dysfunction in a genetic model of sympathetic hyperactivity-induced heart failure in mice. European Journal of Applied Physiology 105 843-850. (doi:10.1007/ s00421-008-0967-4)

Physical Activity Guidelines Advisory Committee 2008 Physical Activity Guidelines Advisory Committee Report, 2008. To the Secretary of Health and Human Services. Part A: executive summary. Nutrition Reviews 67 114-120. (doi:10.1111/j.1753-4887.2008.00136.x)

Quan RD, Madhu M \& Elased KM 2010 Increased urinary angiotensin converting enzyme 2 (ACE2) activity and protein expression in $d b / d b$ diabetic mice. Diabetes 59 A256. (doi:10.2337/db09-0223)

Reich HN, Oudit GY, Penninger JM, Scholey JW \& Herzenberg AM 2008 Decreased glomerular and tubular expression of ACE2 in patients with type 2 diabetes and kidney disease. Kidney International 74 1610-1616. (doi:10.1038/ki.2008.497)

Rhee MK, Herrick K, Ziemer DC, Vaccarino V, Weintraub WS, Narayan KM, Kolm P, Twombly JG \& Phillips LS 2010 Many Americans have prediabetes and should be considered for metformin therapy. Diabetes Care 33 49-54. (doi:10.2337/dc09-0341)

Rocco MV \& Berns JS 2012 KDOQI clinical practice guideline for diabetes and CKD: 2012 update. American Journal of Kidney Diseases 60 850-886. (doi:10.1053/j.ajkd.2012.07.005)

Rodnick KJ, Holloszy JO, Mondon CE \& James DE 1990 Effects of exercise training on insulin-regulatable glucose-transporter protein levels in rat skeletal muscle. Diabetes 39 1425-1429. (doi:10.2337/diab.39.11.1425)

Saeed F, Naga Pavan Kumar DP, Mahendrakar L \& Holley JL 2012 Exerciseinduced proteinuria? Journal of Family Practice 61 23-26.

Salem E, Grobe N \& Elased KM 2014 Insulin treatment attenuates renal ADAM17 and ACE2 shedding in Akita diabetic mice. American Journal of Physiology. Renal Physiology 306 F629-F639. (doi:10.1152/ajprenal. 00516.2013)

Scarpello JH \& Howlett HC 2008 Metformin therapy and clinical uses. Diabetes \& Vascular Disease Research 5 157-167. (doi:10.3132/dvdr.2008.027)

Senador D, Kanakamedala K, Irigoyen MC, Morris M \& Elased KM 2009 Cardiovascular and autonomic phenotype of $d b / d b$ diabetic mice. Experimental Physiology 94 648-658. (doi:10.1113/expphysiol.2008.046474)

Sennott J, Morrissey J, Standley PR \& Broderick TL 2008 Treadmill exercise training fails to reverse defects in glucose, insulin and muscle GLUT4 content in the $d b / d b$ mouse model of diabetes. Pathophysiology 15 173-179. (doi:10.1016/j.pathophys.2008.06.001)

Shaltout HA, Figueroa JP, Rose JC, Diz DI \& Chappell MC 2009 Alterations in circulatory and renal angiotensin-converting enzyme and angiotensinconverting enzyme 2 in fetal programmed hypertension. Hypertension 53 404-408. (doi:10.1161/HYPERTENSIONAHA.108.124339)

Sigal RJ, Kenny GP, Wasserman DH, Castaneda-Sceppa C \& White RD 2006 Physical activity/exercise and type 2 diabetes: a consensus statement from the American Diabetes Association. Diabetes Care 29 1433-1438. (doi:10.2337/dc06-9910)

Tang T \& Reed MJ 2001 Exercise adds to metformin and acarbose efficacy in $d b / d b$ mice. Metabolism 50 1049-1053. (doi:10.1053/meta.2001.25596)

Tessari P \& Tiengo A 2008 Metformin treatment of rats with diet-induced overweight and hypertriglyceridemia decreases plasma triglyceride concentrations, while decreasing triglyceride and increasing ketone body output by the isolated perfused liver. Acta Diabetologica 45 143-145. (doi:10.1007/s00592-008-0032-0)

Tikellis C, Johnston CI, Forbes JM, Burns WC, Burrell LM, Risvanis J \& Cooper ME 2003 Characterization of renal angiotensin-converting enzyme 2 in diabetic nephropathy. Hypertension 41 392-397. (doi:10.1161/01.HYP.0000060689.38912.CB)

Tipnis SR, Hooper NM, Hyde R, Karran E, Christie G \& Turner AJ 2000 A human homolog of angiotensin-converting enzyme. Cloning and functional expression as a captopril-insensitive carboxypeptidase. Journal of Biological Chemistry 275 33238-33243. (doi:10.1074/jbc. M002615200)

Toyama K, Sugiyama S, Oka H, Sumida H \& Ogawa H 2010 Exercise therapy correlates with improving renal function through modifying lipid metabolism in patients with cardiovascular disease and chronic kidney disease. Journal of Cardiology 56 142-146. (doi:10.1016/j.jjcc.2010.06.007)

Tufescu A, Kanazawa M, Ishida A, Lu H, Sasaki Y, Ootaka T, Sato T \& Kohzuki M 2008 Combination of exercise and losartan enhances renoprotective and peripheral effects in spontaneously type 2 diabetes mellitus rats with nephropathy. Journal of Hypertension 26 312-321. (doi:10.1097/HJH.0b013e3282f2450b)

Tuomilehto J, Lindstrom J, Eriksson JG, Valle TT, Hamalainen H, IlanneParikka P, Keinanen-Kiukaanniemi S, Laakso M, Louheranta A, Rastas M et al. 2001 Prevention of type 2 diabetes mellitus by changes in lifestyle among subjects with impaired glucose tolerance. New England Journal of Medicine 344 1343-1350. (doi:10.1056/NEJM200105033441801)

Wang G, Lai FM, Lai KB, Chow KM, Kwan CH, Li KT \& Szeto CC 2008 Urinary mRNA expression of $A C E$ and $A C E 2$ in human type 2 diabetic nephropathy. Diabetologia 51 1062-1067. (doi:10.1007/s00125-008-0988-x)

Weyer C, Bogardus C, Mott DM \& Pratley RE 1999 The natural history of insulin secretory dysfunction and insulin resistance in the pathogenesis of type 2 diabetes mellitus. Journal of Clinical Investigation 104 787-794. (doi:10.1172/JCI7231)

White JM 2003 ADAMs: modulators of cell-cell and cell-matrix interactions. Current Opinion in Cell Biology 15 598-606. (doi:10.1016/j.ceb.2003.08.001)

Wulffele MG, Kooy A, de Zeeuw D, Stehouwer CD \& Gansevoort RT 2004 The effect of metformin on blood pressure, plasma cholesterol and triglycerides in type 2 diabetes mellitus: a systematic review. Journal of Internal Medicine 256 1-14. (doi:10.1111/j.1365-2796.2004.01328.x)

Wysocki J, Garcia-Halpin L, Ye M, Maier C, Sowers K, Burns KD \& Batlle D 2013 Regulation of urinary ACE2 in diabetic mice. American Journal of Physiology. Renal Physiology 305 F600-F611. (doi:10.1152/ajprenal. 00600.2012)

Xiao F, Hiremath S, Knoll G, Zimpelmann J, Srivaratharajah K, Jadhav D, Fergusson D, Kennedy CR \& Burns KD 2012 Increased urinary angiotensin-converting enzyme 2 in renal transplant patients with diabetes. PLoS ONE 7 e37649. (doi:10.1371/journal.pone.0037649)

Xu P, Liu J, Sakaki-Yumoto M \& Derynck R 2012 TACE activation by MAPKmediated regulation of cell surface dimerization and TIMP3 association. Science Signaling 5 ra34. (doi:10.1126/scisignal.2002689)

Ye M, Wysocki J, William J, Soler MJ, Cokic I \& Batlle D 2006 Glomerular localization and expression of angiotensin-converting enzyme 2 and angiotensin-converting enzyme: implications for albuminuria in diabetes. Journal of the American Society of Nephrology 17 3067-3075. (doi:10.1681/ASN.2006050423)

Yki-Jarvinen H \& Koivisto VA 1983 Effects of body composition on insulin sensitivity. Diabetes 32 965-969. (doi:10.2337/diab.32.10.965)

Zapecka-Dubno B, Czyzyk A, Dworak A \& Bak MI 1999 Effect of oral antidiabetic agents on plasma amylin level in patients with noninsulin-dependent diabetes mellitus (type 2). Arzneimittel-Forschung 49 330-334. (doi:10.1055/s-0031-1300423)

Zhou G, Myers R, Li Y, Chen Y, Shen X, Fenyk-Melody J, Wu M, Ventre J, Doebber T, Fujii N et al. 2001 Role of AMP-activated protein kinase in mechanism of metformin action. Journal of Clinical Investigation 108 1167-1174. (doi:10.1172/JCI13505)

Zinman B \& Vranic M 1985 Diabetes and exercise. Medical Clinics of North America 69 145-157.

Received in final form 1 February 2014

Accepted 25 February 2014 http://joe.endocrinology-journals.org DOI: 10.1530/JOE-13-0532
() 2014 Society for Endocrinology Printed in Great Britain 